medRxiv preprint doi: https://doi.org/10.1101/2020.04.23.20076653; this version posted April 27, 2020. The copyright holder for this preprint (which was not certified by peer review) is the author/funder, who has granted medRxiv a license to display the preprint in perpetuity. It is made available under a CC-BY-NC-ND 4.0 International license.

\title{
Clinical and historical features associated with severe COVID-19 infection: a systematic review
}

Pigoga, $\mathrm{JL}^{1}$, MPH; Friedman, $\mathrm{A}^{1,2}$, MSc; Broccoli, $\mathrm{M}^{3}$, MD; Hirner, $\mathrm{S}^{4}$, MS; Naidoo, $\mathrm{AV}^{1}$, FCEM(SA); Singh, $\mathrm{S}^{1}$, FCEM(SA); Werner, $\mathrm{K}^{1}$, MSc; Wallis, LA ${ }^{1}$, MBChB, FRCEM, PhD

\section{Author affiliations}

1. Division of Emergency Medicine, University of Cape Town, Cape Town, South Africa

2. University of California, San Francisco, San Francisco, California, USA

3. Department of Emergency Medicine, Boston Medical Center, Boston, Massachusetts, USA

4. University of Colorado School of Medicine, Aurora, CO, USA

\begin{abstract}
Background: There is an urgent need for rapid assessment methods to guide pathways of care for COVID-19 patients, as frontline providers need to make challenging decisions surrounding rationing of resources. This study aimed to evaluate existing literature for factors associated with COVID-19 illness severity.
\end{abstract}

Methods: A systematic review identified all studies published between 1/12/19 and 19/4/20 that used primary data and inferential statistics to assess associations between the outcome of interest - disease severity - and historical or clinical variables. PubMed, Scopus, Web of Science, and the WHO Database of Publications on Coronavirus Disease were searched. Data were independently extracted and crosschecked independently by two reviewers using PRISMA guidelines, after which they were descriptively analysed. Quality and risk of bias in available evidence were assessed using the Grading of Recommendations, Assessment, Development and Evaluations (GRADE) framework. This review was registered with PROSPERO, registration number CRD42020178098.

Results: Of the 6202 relevant articles found, 63 were eligible for inclusion; these studies analysed data from 17648 COVID-19 patients. The majority $(\mathrm{n}=57,90.5 \%)$ were from China and nearly all $(\mathrm{n}=51$, $90.5 \%$ ) focussed on admitted adult patients. Patients had a median age of 52.5 years and $52.8 \%$ were male. The predictors most frequently associated with COVID-19 disease severity were age, absolute lymphocyte count, hypertension, lactate dehydrogenase (LDH), C-reactive protein (CRP), and history of any pre-existing medical condition.

Conclusion: This study identified multiple variables likely to be predictive of severe COVID-19 illness. Due to the novelty of SARS-CoV-2 infection, there is currently no severity prediction tool designed to, or validated for, COVID-19 illness severity. Findings may inform such a tool that can offer guidance on clinical treatment and disposition, and ultimately reduce morbidity and mortality due to the pandemic. 
medRxiv preprint doi: https://doi.org/10.1101/2020.04.23.20076653; this version posted April 27, 2020. The copyright holder for this preprint

(which was not certified by peer review) is the author/funder, who has granted medRxiv a license to display the preprint in perpetuity.

It is made available under a CC-BY-NC-ND 4.0 International license.

\section{INTRODUCTION}

Despite containment efforts, COVID-19 has reached pandemic status. As of 21 April 2020, there are 2.5 million confirmed cases worldwide, with over 170,000 deaths; ${ }^{12}$ these numbers are only expected to grow in the coming weeks and months. Although data surrounding the novel coronavirus are rapidly evolving, initial estimates depict a dire situation: between $15 \%$ and $20 \%$ of infections lead to severe or critical disease. ${ }^{2}{ }^{3}$ Highly vulnerable populations, compromised by factors such as malnutrition and comorbid diseases, are believed to be at greater risk of developing severe and critical disease. ${ }^{4}$ Mortality has varied across settings, but early data suggest a case fatality rate ranging from $0.5 \%$ to $4.5 \% .{ }^{5-8} \mathrm{As}$ COVID-19 spreads, healthcare systems worldwide are being strained. ${ }^{10}$ Early recognition, resuscitation and referral have proven key to effective responses, yielding lower mortality. ${ }^{11}$ High volumes of patients in need of critical care limit systems' abilities to provide such care; this is already occurring even in the most highly-resourced settings. ${ }^{910}$ It is increasingly likely that the countries with the most limited capacity to respond will soon be affected on a large scale. ${ }^{12}$ Many low-resource settings (LRS) have scarce critical care resources, with limitations in the availability of oxygen and other basic resources as well as healthcare provider shortages. ${ }^{1314}$ While ongoing acute and emergency care system strengthening efforts are underway and showing impact in many of these settings, these systems will not be able to keep pace with the emerging demand. ${ }^{12}$ Immediate targeted efforts are needed to assist stressed healthcare systems around the globe in managing and treating large numbers of acutely ill COVID-19 patients. ${ }^{12}$

Frontline providers in emergency units (EUs) need to make challenging decisions surrounding rationing of resources, including oxygen and ventilators, upon initial assessment of COVID-19 patients. Clinical guidance for evaluating patients' respiratory needs and subsequent dispositions is essential, particularly in LRS. A range of scoring systems are available to guide care for severely ill patients. While these tools may have some utility in predicting COVID-19 patient severity, they are likely limited in this unique context. Some scores are designed for specific care settings, such as intensive care units (ICUs), a very scarce resource in LRS. ${ }^{15}$ While selected COVID-19 patients can be treated in ICUs, most patients are less critical, requiring interventions more appropriate for general ward and EU settings. Thus, a tool predicting outcomes based solely on those already admitted to ICU may have reduced utility across the range of illness severity seen in this disease. Other scoring systems were purposedesigned for patients presenting with specific conditions, such as pneumonia and sepsis. ${ }^{15}{ }^{16}$ Conditionspecific tools may be of some use in assessing COVID-19 patients but are likely limited in that these patients initially present with a range of symptoms, only some of which involve respiratory disease or septic shock. ${ }^{17}$ High burdens of data entry seen in many tools can lead to increased time-to-decision making and frequent missing data points. ${ }^{18-20}$ Some also involve additional investigations, including blood tests and imaging, ${ }^{151-23}$ that have very limited availability in LRS.

In the context of the COVID-19 crisis, a low-input severity scoring tool could be a cornerstone of ensuring timely access to appropriate care and justified use of critically limited resources. In order to identify or develop a severity assessment tool appropriate for COVID-19 patients, factors contributing to, and predictive of, patient severity must first be understood. This study aimed to systematically evaluate existing COVID-19 literature for relationships between historical characteristics and clinical presentations and investigations, and illness severity. 
medRxiv preprint doi: https://doi.org/10.1101/2020.04.23.20076653; this version posted April 27, 2020. The copyright holder for this preprint (which was not certified by peer review) is the author/funder, who has granted medRxiv a license to display the preprint in perpetuity. It is made available under a CC-BY-NC-ND 4.0 International license.

\section{METHODS}

A systematic review was conducted to identify papers that studied potential associations between demographics, comorbidities, clinical presentations and investigational studies, and COVID-19 illness severity. The Preferred Reporting Items for Systematic Reviews and Meta-Analysis (PRISMA) guidelines were adhered to throughout this process. ${ }^{24}$

\section{Search strategy and selection criteria}

Three online databases (PubMed, Scopus, and Web of Science) were searched using a combination of free-text phrases and medical subject headings. Results were restricted to those in the English, Spanish, and Mandarin languages, published between 01 December 2019 and 19 April 2020. Search terms related to COVID-19 infection ("NCoV", "Coronavirus", "severe acute respiratory syndrome coronavirus 2", "COVID”, "COVID-19", "Coronavirus infections") and illness severity ("Severity of Illness Index", "severity", "critical”, "critical illness", "critical care", "patient admission", "length of stay", "outcome", "morbidity", "mortality", "death", "respiratory insufficiency", "respiratory distress syndrome, adult", and "respiration, artificial") were used in combination with those for demographics ("demographic", "demographic", "age", "sex", and "gender"), historical features ("comorbidity", "comorbidity"), "pre-existing", and "condition"), clinical presentation ("signs and symptoms", "symptom", "characteristic", "clinical" and, "presentation"), and diagnostic investigations ("investigation", "laboratory", "blood test", "imaging", "X-ray" and, "CT"). Refer to appendix 1 for full search strategy.

All publications in the World Health Organization's (WHO) Database of Publications on Coronavirus Disease (COVID-19) were also included. ${ }^{25}$ Reference lists of all texts eligible full texts were reviewed to identify additional relevant literature.

Duplicates were manually removed. All articles were screened for inclusion by two independent reviewers (JLP, KW, SS, AVN), after which a third reviewer (AF, JLP, MB, SS, AVN) retrieved each eligible full-text and considered for inclusion. Two discrepancies in agreement were resolved through discussion.

This study included all full-text manuscripts, both pre-print and published, that provided data on associations between the outcome of interest - disease severity - and demographics, comorbidities, symptoms, vital signs, and/or investigational studies of confirmed COVID-19 patients admitted to hospitals. Research-based correspondence pieces were also included, as this is an additional format of rapid research dissemination in the COVID-19 era. Those not directly evaluating primary data, including literature reviews and meta-analyses, were excluded, as were opinion and editorial pieces, case reports, and clinical management guidelines. A range of definitions and parameters of illness severity were considered acceptable as comparator outcomes, including disease severity itself (as defined by the article's authors), as well as proxy measures for disease severity, such as inpatient mortality and ICU admission ${ }^{26}$. Manuscripts that did not include statistical analyses evaluating significance were excluded. There were no restrictions to study design. Studies evaluating exclusively children or pregnant populations were excluded.

\section{Data analysis}

Data extracted from each article included author(s); title; countries involved; study population demographics; measure and definition of disease severity; and each presenting symptom, comorbidity, initial vital sign, and investigational study that was statistically assessed against disease severity, along 
medRxiv preprint doi: https://doi.org/10.1101/2020.04.23.20076653; this version posted April 27, 2020. The copyright holder for this preprint (which was not certified by peer review) is the author/funder, who has granted medRxiv a license to display the preprint in perpetuity. It is made available under a CC-BY-NC-ND 4.0 International license.

with notation of whether each variable was found to be significantly associated with severity. Variables reported with a $p$-value $\leq 0.05$ were considered significantly associated with illness severity.

One reviewer (AF, JLP, MB, SH, SS, AVN) extracted data, and second reviewer (AF and JLP) crosschecked all extractions. All extracted variables were documented categorically as 'significant', 'not significant' or 'not reported'. Grading of Recommendations, Assessment, Development and Evaluations (GRADE) framework ${ }^{27}$ was used to assess quality of and bias in study evidence. Two reviewers (AF and JLP) graded each study, reaching consensus via discussion when necessary.

A descriptive analysis of the number of papers that reported each variable as significantly associated with illness severity was conducted. No tests of statistical significance were conducted.

\section{Patient and public involvement}

Given the nature of this review, it was not appropriate to involve patients or the public in this study's design or execution.

\section{RESULTS}

The literature search identified 6202 articles across four databases (Figure 1). Thirty-one relevant publications referenced in the databases' articles were also found. After removing duplicates, 5770 studies remained; title and abstract screening led to the removal of $5361(92.9 \%)$ of these as they did not meet inclusion criteria. Upon review of 409 full-texts, 350 articles were excluded: $289(82 \cdot 6 \%)$ did not include significance testing for relevant variables, $55(15 \cdot 7 \%)$ did not evaluate primary data, and 2 $(0 \cdot 6 \%)$ were in a language other than English, Mandarin, or Spanish.

Sixty-three articles were eligible for inclusion (Table 1). The majority ( $\mathrm{n}=57,90 \cdot 5 \%)$ were from China; two publications were available from the United States and one each from Italy, France, South Korea, and Singapore. Most publications $(\mathrm{n}=61,96 \cdot 8 \%)$ were in English; two $(3 \cdot 2 \%)$ were only available in Mandarin. All studies were observational cohort studies; 57 (90.5\%) retrospective and six $(9 \cdot 5 \%)$ prospective. Due in large part to study design, nearly all $(n=62,98 \cdot 4 \%)$ studies were of low quality. One (1.6\%) study was of moderate quality. Together, these studies analysed data from 17648 patients diagnosed with COVID-19 by laboratory technique (PCR or RT-PCR). Sample sizes in these studies ranged from 12 to 4103 patients, with a mean of 280 . Of the 58 publications reporting sex, a median $52 \cdot 8 \%$ patients were male. The median age was 52.5 years across 56 reporting studies. Eight publications included both children and adults. Four publications focused on specific populations, including healthcare workers $(n=2)$, and those with cancer $(n=1)$, and cardiovascular disease $(n=1)$; the remaining 59 studies noted no population restrictions. Approximately $41 \%(n=26)$ of publications defined illness severity by the National Health Committee of the People's Republic of China's (NHC) guidelines (Table 2$)^{25}$. Fourteen studies $(22 \cdot 2 \%)$ evaluated inpatient mortality, and another six $(9 \cdot 5 \%)$ studied ICU admission.

The most commonly analysed variables in relation to patient severity were age, sex, absolute lymphocyte count, and hypertension. The predictors most frequently associated with COVID-19 disease severity were age, absolute lymphocyte count, hypertension, lactate dehydrogenase (LDH), C-reactive protein (CRP), and history of any pre-existing medical condition.

Age was commonly identified as a significant predictor of illness severity (Table 3 ). The comorbidities most often reported as significant in patients with poorer outcomes were history of any pre-existing medical condition, hypertension, diabetes, and cardiovascular disease (Table 3). The presenting 
medRxiv preprint doi: https://doi.org/10.1101/2020.04.23.20076653; this version posted April 27, 2020. The copyright holder for this preprint

(which was not certified by peer review) is the author/funder, who has granted medRxiv a license to display the preprint in perpetuity.

It is made available under a CC-BY-NC-ND 4.0 International license.

symptom most frequently associated with severe disease was dyspnoea or difficulty in breathing (Table 4). All other symptoms, including fever or chills, cough, sputum production, myalgias, and diarrhoea among others, were more frequently not associated with severe disease. Six of ten $(60 \%)$ studies evaluating respiratory rate for initial vitals found it to be a predictor of severity, and four of five $(80 \%)$ for $\mathrm{SpO} 2$.

The most commonly associated laboratory values were absolute lymphocyte count, LDH, CRP, Ddimer, and procalcitonin (Table 5). Among associated laboratory values, $\mathrm{PaO} 2 / \mathrm{FiO} 2$, N-terminal btype natriuretic peptide (NT-proBNP) and blood glucose were each consistently reported as significant across multiple studies. Abnormal CT was significant in ten of $16(62.5 \%)$ studies, and abnormal chest X-ray in two of four (50\%) (Table 5).

\section{CONCLUSION}

The novelty of SARS-CoV-2 infection has led to many hypotheses regarding potentially significant predictors of patient illness. This study aimed to provide clarity around potential predictors by presenting a systematic review of the features most frequently and consistently associated with COVID-19 illness severity. The available literature evaluates a broad range of clinical characteristics and investigations, highlighting variables likely to be significantly associated with illness severity, including age, history of pre-existing medical conditions, dyspnoea on presentation, and a range of blood tests.

In line with several publications, ${ }^{28-30}$ age was identified as a predictor of illness severity in nearly all studies. However, not all studies addressed confounding in their methodology. It is not clear whether age is an independent predictor for severity due to decreased physiological reserve or if increased rates of comorbidities amongst elderly populations influence its significance. Results suggest that any preexisting condition may put COVID-19 patients at higher risk of poor outcomes. But, when looking at specific conditions, few comorbidities were found to be consistently significant across the literature. Hypertension, cardiovascular disease, and body mass index (BMI) were found to be significant predictors in the majority of instances where they were evaluated; these should be assessed further in future investigations

In clinical practice, clinical discriminators and vital signs play important roles in determining acuity. Shortness of breath or dyspnoea was the only presenting symptom reported as a significant predictor of severity across these studies. An earlier meta-analysis of COVID-19 data also supports this conclusion. ${ }^{31}$ Dyspnoea is easy to assess and already being used in many settings for COVID-19 screening, ${ }^{31-33}$ making it a candidate for potential inclusion in a COVID-19 severity scoring tool. Data on initial vital signs were inconclusive.

Although a large portion of potentially predictive variables depend on blood investigations, these predictors may have limited utility in the initial management of COVID-19 disease, especially in LRS: Faced with scarce time and resources, and overwhelming patient numbers, clinicians around the world are in need of near-immediate indicators of illness severity. Potentially relevant severity calculators such as the Pneumonia Severity Index and CURB-65, require blood investigations and imaging to predict mortality, and are based on non-COVID-19 pneumonia, ${ }^{23}{ }^{34}$ limiting their utility in the pandemic.

Due to the novelty of SARS-CoV-2 infection, there are currently no scoring systems validated for COVID-19 illness severity assessment either at the initial point of entry to the healthcare system or 
medRxiv preprint doi: https://doi.org/10.1101/2020.04.23.20076653; this version posted April 27, 2020. The copyright holder for this preprint

(which was not certified by peer review) is the author/funder, who has granted medRxiv a license to display the preprint in perpetuity.

It is made available under a CC-BY-NC-ND 4.0 International license .

during admission. Such a tool could enable rapid classification of patients' illness severity to determine disposition and resource allocation, aiding overwhelmed healthcare systems facing limited resources. It could assist frontline providers in decision-making surrounding resource allocation, including both the physical - e.g. oxygen and mechanical ventilation - and human resources necessary to oversee such interventions in a timely, appropriate manner for the rapidly increasing volume of COVID-19 patients.

Most LRS already suffered from scarcities of oxygen, mechanical ventilation and ICU beds preCOVID- $19,{ }^{35}$ and the current resource constraints seen in highly-resourced settings will likely be even more extreme in LRS. ${ }^{36}{ }^{37}$ Ethical allocation of resources is expected to become a necessity in all settings, as providers will have to divide resources across both COVID-19 and non-COVID-19 patients, many of whom will have similar prognoses. ${ }^{38}$ Though a severity scoring tool may identify a patient's need for oxygen or mechanical ventilation, broader resource allocation for all patient populations requires ethical frameworks beyond such a tool's scope. This review's findings may have utility as components of a COVID-19-specific severity scoring tool that could offer guidance on clinical treatment and disposition, and ultimately reduce morbidity and mortality due to the COVID-19 pandemic.

Some discrepancies exist between our findings and calculators currently being used to evaluate COVID19 patients, namely on the significance of initial vitals, presenting symptoms, laboratory values and imaging findings. Though our findings were inconclusive in regard to initial vitals, one study reported that qSOFA was predictive of COVID-19 illness severity, ${ }^{39}$ indicating that altered mental status, tachypnoea and systolic blood pressure $\leq 100 \mathrm{mmHg}$ could be predictive in a severity scoring tool. Most pneumonia clinical calculators to predict illness severity rely on laboratory and imaging investigations that were insignificant in our systematic review - aside from glucose, absolute lymphocyte count and $\mathrm{PaO} 2 / \mathrm{FiO} 2$ - and are not immediately available in most LRS. Various calculators also emphasise sex and pulmonary co-morbidities, which were found to be independently insignificant in our review. The discrepancies between our systematic review and the clinical calculators of illness severity being used in this pandemic warrant a COVID-19 specific-calculator based on the emerging evidence rather than single-institution experience to facilitate illness severity stratification.

Due to the emergent COVID-19 pandemic and need for data to inform responses, rapid efforts are being made to publish any available information. Our review included research-based correspondence and pre-print articles alongside peer-reviewed publications, all of which were in the form of observational cohort studies. However, all studies performed well against GRADE criteria, scoring at least as well as is expected for cohort studies (low quality or above).

An overwhelming majority of studies originated in China; this suggests that there may be increased homogeneity in the data and that results might not be translatable to other settings. It could not be confirmed that none of the publications used populations from the same patient database.

Findings of this study may also be limited in that they are solely descriptive, lacking any testing of statistical significance. Numerous definitions for, and proxy measures of, illness severity were presented in the primary literature included in this review. While this variance may have influenced results, it could not be avoided given the urgency of the COVID-19 pandemic and lack of existing evidence.

This systematic review presents the features most associated with COVID-19 illness severity based on frequency and consistency of reporting publications. These findings could aid frontline providers in 
medRxiv preprint doi: https://doi.org/10.1101/2020.04.23.20076653; this version posted April 27, 2020. The copyright holder for this preprint (which was not certified by peer review) is the author/funder, who has granted medRxiv a license to display the preprint in perpetuity. It is made available under a CC-BY-NC-ND 4.0 International license.

determining how to allocate scarce resources, namely oxygen and mechanical ventilation, in a timely and appropriate manner for the rapidly increasing volume of COVID-19 patients around the world, but especially in LRS. It is our hope that by using significant variables such as age, history of comorbidity, and dyspnoea as a presenting symptom, providers in LRS can quickly predict illness severity to guide clinical treatment and disposition of patients with COVID-19 disease. Given the urgency of the pandemic and the almost universally low-quality of data, future research collaborations with larger samples and prospective designs are critical to improving COVID-19 illness severity prediction and subsequent management.

Contributors: LAW, JLP, and MB designed the study. JLP performed the database searches. JLP, KW, SS, and AVN screened articles titles and abstracts for inclusion. AF, JLP, MB, SS and AVN screened eligible full texts for inclusion. AF, JLP, MB, SH, SS, and AVN extracted data. JLP and AF crosschecked all data extractions, assessed quality of included studies, performed data analysis, and drafted the manuscript. All authors contributed to revising the manuscript and have approved of the final version. LAW is the guarantor.

Funding: No funding was received for this study.

Competing interests: None declared.

Data availability statement: Additional extracted data not provided in-text or as supplementary information are available upon request. 
medRxiv preprint doi: https://doi.org/10.1101/2020.04.23.20076653; this version posted April 27, 2020. The copyright holder for this preprint

(which was not certified by peer review) is the author/funder, who has granted medRxiv a license to display the preprint in perpetuity. It is made available under a CC-BY-NC-ND 4.0 International license.

\section{REFERENCES}

1. COVID Cases 2020 [Available from: https://www.worldometers.info/coronavirus/ accessed 29 March 2020.

2. Coronavirus disease (COVID-19) outbreak Geneva: World Health Organization; 2020 [Available from: https://www.who.int/emergencies/diseases/novel-coronavirus-2019 accessed 20 March 2020.

3. Report of the WHO-China Joint Mission on Coronavirus Disease 2019 (COVID-19) Geneva: World Health Organization, 2020.

4. Yang J, Zheng Y, Gou X, et al. Prevalence of comorbidities in the novel Wuhan coronavirus (COVID-19) infection: a systematic review and meta-analysis. Int $J$ Infect Dis 2020 doi: 10.1016/j.ijid.2020.03.017 [published Online First: 2020/03/17]

5. Korean Society of Infectious D, Korean Society of Pediatric Infectious D, Korean Society of E, et al. Report on the Epidemiological Features of Coronavirus Disease 2019 (COVID-19) Outbreak in the Republic of Korea from January 19 to March 2, 2020. J Korean Med Sci 2020;35(10):e112. doi: 10.3346/jkms.2020.35.e112 [published Online First: 2020/03/17]

6. Onder G, Rezza G, Brusaferro S. Case-Fatality Rate and Characteristics of Patients Dying in Relation to COVID-19 in Italy. JAMA 2020 doi: 10.1001/jama.2020.4683 [published Online First: 2020/03/24]

7. Yang S, Cao P, Du P, et al. Early estimation of the case fatality rate of COVID-19 in mainland China: a data-driven analysis. Ann Transl Med 2020;8(4):128. doi: 10.21037/atm.2020.02.66 [published Online First: 2020/03/17]

8. Coronavirus disease 2019 (COVID-19) Situation Report - 66. Geneva World Health Organization 2020.

9. Lai S, Bogoch I, Watts A, et al. Preliminary risk analysis of 2019 novel coronavirus spread within and beyond China., 2020.

10. Liew MF, Siow WT, MacLaren G, et al. Preparing for COVID-19: early experience from an intensive care unit in Singapore. Crit Care 2020;24(1):83. doi: 10.1186/s13054-020-2814-x [published Online First: 2020/03/11]

11. Sun Q, Qiu H, Huang M, et al. Lower mortality of COVID-19 by early recognition and intervention: experience from Jiangsu Province. Ann Intensive Care 2020;10(1):33. doi: 10.1186/s13613020-00650-2 [published Online First: 2020/03/20]

12. Gilbert M, Pullano G, Pinotti F, et al. Preparedness and vulnerability of African countries against importations of COVID-19: a modelling study. Lancet 2020;395(10227):871-77. doi: 10.1016/S0140-6736(20)30411-6 [published Online First: 2020/02/24]

13. Chavula C, Pigoga JL, Kafwamfwa M, et al. A cross-sectional evaluation of emergency care capacity at public hospitals in Zambia 2018.

14. Bitter CC, Rice B, Periyanayagam U, et al. What resources are used in emergency departments in rural sub-Saharan Africa? A retrospective analysis of patient care in a district-level hospital in Uganda. BMJ Open 2018;8(2):e019024. doi: 10.1136/bmjopen-2017-019024 [published Online First: 2018/02/27]

15. Lambden S, Laterre PF, Levy MM, et al. The SOFA score-development, utility and challenges of accurate assessment in clinical trials. Crit Care 2019;23(1):374. doi: 10.1186/s13054-0192663-7 [published Online First: 2019/11/30]

16. Lim WS, van der Eerden MM, Laing R, et al. Defining community acquired pneumonia severity on presentation to hospital: an international derivation and validation study. Thorax 2003;58(5):377-82. doi: 10.1136/thorax.58.5.377 [published Online First: 2003/05/03]

17. Adhikari SP, Meng S, Wu YJ, et al. Epidemiology, causes, clinical manifestation and diagnosis, prevention and control of coronavirus disease (COVID-19) during the early outbreak period: a 
medRxiv preprint doi: https://doi.org/10.1101/2020.04.23.20076653; this version posted April 27, 2020. The copyright holder for this preprint (which was not certified by peer review) is the author/funder, who has granted medRxiv a license to display the preprint in perpetuity. It is made available under a CC-BY-NC-ND 4.0 International license.

scoping review. Infect Dis Poverty 2020;9(1):29. doi: 10.1186/s40249-020-00646-x [published Online First: 2020/03/19]

18. Afessa B, Keegan MT, Gajic O, et al. The influence of missing components of the Acute Physiology Score of APACHE III on the measurement of ICU performance. Intensive Care Med 2005;31(11):1537-43. doi: 10.1007/s00134-005-2751-9 [published Online First: 2005/10/06]

19. Jentzer JC, Bennett C, Wiley BM, et al. Predictive value of individual Sequential Organ Failure Assessment sub-scores for mortality in the cardiac intensive care unit. PLoS One 2019;14(5):e0216177. doi: 10.1371/journal.pone.0216177 [published Online First: 2019/05/21]

20. Lo R, Leung LY, Brabrand M, et al. qSOFA is a Poor Predictor of Short-Term Mortality in All Patients: A Systematic Review of 410,000 Patients. Journal of clinical medicine 2019;8(1):61. doi: https://doi.org/10.3390/jcm8010061

21. Yandiola PPE, Capelastegui A, Quintana J, et al. Prospective comparison of severity scores for predicting clinically relevant outcomes for patients hospitalized with community-acquired pneumonia. Chest 2009;135(6):1572-79. doi: 10.1378/chest.08-2179 [published Online First: 2009/01/15]

22. Charles PG, Wolfe R, Whitby M, et al. SMART-COP: a tool for predicting the need for intensive respiratory or vasopressor support in community-acquired pneumonia. Clin Infect Dis 2008;47(3):375-84. doi: 10.1086/589754 [published Online First: 2008/06/19]

23. Kim MA, Park JS, Lee CW, et al. Pneumonia severity index in viral community acquired pneumonia in adults. PLoS One 2019;14(3):e0210102. doi: 10.1371/journal.pone.0210102 [published Online First: 2019/03/07]

24. Moher D, Liberati A, Tetzlaff J, et al. Preferred reporting items for systematic reviews and metaanalyses: the PRISMA statement. Int J Surg 2010;8(5):336-41. doi: 10.1016/j.ijsu.2010.02.007 [published Online First: 2010/02/23]

25. Database of publications on coronavirus disease (COVID-19) Geneva: World Health Organization; 2020 [Available from: https:/www.who.int/emergencies/diseases/novel-coronavirus2019/global-research-on-novel-coronavirus-2019-ncov accessed 03/30/2020.

26. Twomey M, Wallis LA, Myers JE. Limitations in validating emergency department triage scales. Emerg Med J 2007;24(7):477-9. doi: 10.1136/emj.2007.046383 [published Online First: 2007/06/22]

27. Guyatt GH, Oxman AD, Vist GE, et al. GRADE: an emerging consensus on rating quality of evidence and strength of recommendations. BMJ 2008;336(7650):924-6. doi: 10.1136/bmj.39489.470347.AD [published Online First: 2008/04/26]

28. Liu K, Chen Y, Lin R, et al. Clinical features of COVID-19 in elderly patients: A comparison with young and middle-aged patients. $J$ Infect 2020 doi: 10.1016/j.jinf.2020.03.005 [published Online First: 2020/03/17]

29. Shi Y, Yu X, Zhao H, et al. Host susceptibility to severe COVID-19 and establishment of a host risk score: findings of 487 cases outside Wuhan. Crit Care 2020;24(1):108. doi: 10.1186/s13054-020-2833-7 [published Online First: 2020/03/20]

30. Chen J, Qi T, Liu L, et al. Clinical progression of patients with COVID-19 in Shanghai, China. $J$ Infect 2020 doi: 10.1016/j.jinf.2020.03.004 [published Online First: 2020/03/17]

31. ICNARC report on COVID-19 in critical care London: Intensive Care National Audit and Research Centre 2020.

32. Lin M, Beliavsky A, Katz K, et al. What can early Canadian experience screening for COVID-19 teach us about how to prepare for a pandemic? CMAJ 2020 doi: 10.1503/cmaj.200305 [published Online First: 2020/03/08] 
medRxiv preprint doi: https://doi.org/10.1101/2020.04.23.20076653; this version posted April 27, 2020. The copyright holder for this preprint (which was not certified by peer review) is the author/funder, who has granted medRxiv a license to display the preprint in perpetuity. It is made available under a CC-BY-NC-ND 4.0 International license.

33. Clinical management of severe acute respiratory infection (SARI) when COVID-19 disease is suspected. Interim guidance, 13 March 2020. . Geneva: World Health Organization, 2020.

34. Macfarlane J. CURB-65 Score for Pneumonia Severity 2020 [Available from: https://www.mdcalc.com/curb-65-score-pneumonia-severity.

35. Krishnamoorthy V, Vavilala MS, Mock CN. The need for ventilators in the developing world: An opportunity to improve care and save lives. J Glob Health 2014;4(1):010303. doi: 10.7189/jogh.04.010303 [published Online First: 2014/07/01]

36. Ginsburg AS, Van Cleve WC, I. W. Thompson IWM, et al. Oxygen and Pulse Oximetry in Childhood Pneumonia: A Survey of Healthcare Providers in Resource-limited Settings. Journal of Tropical Pediatrics 2011;58(5):389-93. doi: 10.1093/tropej/fmr103

37. Murthy S, Leligdowicz A, Adhikari NK. Intensive Care Unit Capacity in Low-Income Countries: A Systematic Review. PLoS One 2015;10(1) doi: 10.1371/journal.pone.0116949

38. Emanuel EJ, Persad G, Upshur R, et al. Fair Allocation of Scarce Medical Resources in the Time of Covid-19. N Engl J Med 2020 doi: 10.1056/NEJMsb2005114 [published Online First: 2020/03/24]

39. Zhou F, Yu T, Du R, et al. Clinical course and risk factors for mortality of adult inpatients with COVID-19 in Wuhan, China: a retrospective cohort study. Lancet 2020 doi: 10.1016/S01406736(20)30566-3 [published Online First: 2020/03/15]

40. Huang C, Wang Y, Li X, et al. Clinical features of patients infected with 2019 novel coronavirus in Wuhan, China. Lancet 2020;395(10223):497-506. doi: 10.1016/S0140-6736(20)30183-5 [published Online First: 2020/01/28]

41. Peng YD, Meng K, Guan HQ, et al. [Clinical characteristics and outcomes of 112 cardiovascular disease patients infected by 2019-nCoV]. Zhonghua Xin Xue Guan Bing Za Zhi 2020;48(0):E004. doi: 10.3760/cma.j.cn112148-20200220-00105 [published Online First: 2020/03/04]

42. Liu Y, Yang Y, Zhang C, et al. Clinical and biochemical indexes from 2019-nCoV infected patients linked to viral loads and lung injury. Sci China Life Sci 2020;63(3):364-74. doi: 10.1007/s11427-020-1643-8 [published Online First: 2020/02/13]

43. Zheng H, Zhang M, Yang C, et al. Elevated exhaustion levels and reduced functional diversity of T cells in peripheral blood may predict severe progression in COVID-19 patients. Cell Mol Immunol 2020 doi: 10.1038/s41423-020-0401-3

44. Lei C, Huiguo L, Wei L, et al. Analysis of clinical characteristics of 29 cases of new type coronavirus pneumonia. Chinese Journal of Tuberculosis and Respiratory Diseases 2020 doi: 10.3760 / cma.j.issn.1001-0939.2020.0005

45. Min L, Min L, Peng H, et al. Analysis of clinical characteristics of 30 cases of new coronavirus pneumonia in medical staff.

Chinese Journal of Tuberculosis and Respiratory Diseases 2020;43 doi: 10.3760 / cma.j.issn.10010939.2020 .0016

46. Zhou B, She J, Wang Y, et al. The clinical characteristics of myocardial injury in severe and very severe patients with 2019 Novel Coronavirus Disease. Journal of Infection 2020 doi: 10.1016/j.jinf.2020.03.021

47. Gao Y, Li T, Han M, et al. Diagnostic Utility of Clinical Laboratory Data Determinations for Patients with the Severe COVID-19. J Med Virol 2020 doi: 10.1002/jmv.25770 [published Online First: 2020/03/18]

48. Shen C, Yu N, Cai S, et al. Quantitative computed tomography analysis for stratifying the severity of Coronavirus Disease 2019. Journal of Pharmaceutical Analysis 2020 doi: 10.1016/j.jpha.2020.03.004 
medRxiv preprint doi: https://doi.org/10.1101/2020.04.23.20076653; this version posted April 27, 2020. The copyright holder for this preprint (which was not certified by peer review) is the author/funder, who has granted medRxiv a license to display the preprint in perpetuity. It is made available under a CC-BY-NC-ND 4.0 International license.

49. Zhou W, Zhong Z, Xie X. Relation between chest CT findings and clinical conditions of Coronavirus Disease (COVID-19) pneumonia: A multicenter study. AJR Am J Roentgenol 2020;3 doi: 10.2214/AJR.20.22976

50. Liang W, Guan W, Chen R, et al. Cancer patients in SARS-CoV-2 infection: a nationwide analysis in China. Lancet Oncol 2020;21(3):335-37. doi: 10.1016/S1470-2045(20)30096-6 [published Online First: 2020/02/19]

51. Yuan M, Yin W, Tao Z, et al. Association of radiologic findings with mortality of patients infected with 2019 novel coronavirus in Wuhan, China. PLoS One 2020;15(3):e0230548. doi: 10.1371/journal.pone.0230548 [published Online First: 2020/03/20]

52. Liu JL, Y., Xiang P, Pu L, et al. Neutrophil-to-lymphocyte ratio predicts severe illness patients with 2019 Novel Coronavirus in the early stage. MedRxiv 2020 doi: 10.1101/2020.02.10.20021584

53. Wang Z, Yang B, Li Q, et al. Clinical Features of 69 Cases with Coronavirus Disease 2019 in Wuhan, China. Clin Infect Dis 2020 doi: 10.1093/cid/ciaa272 [published Online First: 2020/03/17]

54. Fan BE, Chong VCL, Chan SSW, et al. Hematologic parameters in patients with COVID-19 infection. Am J Hematol 2020 doi: 10.1002/ajh.25774 [published Online First: 2020/03/05]

55. Liu W, Tao ZW, Lei W, et al. Analysis of factors associated with disease outcomes in hospitalized patients with 2019 novel coronavirus disease. Chin Med J (Engl) 2020 doi: 10.1097/CM9.0000000000000775 [published Online First: 2020/03/03]

56. Cao J, Hu X, Cheng W, et al. Clinical features and short-term outcomes of 18 patients with corona virus disease 2019 in intensive care unit. Intensive Care Med 2020 doi: 10.1007/s00134-02005987-7 [published Online First: 2020/03/04]

57. Li K, Wu J, Wu F, et al. The Clinical and Chest CT Features Associated with Severe and Critical COVID-19 Pneumonia. Invest Radiol 2020 doi: 10.1097/RLI.000000000000672 [published Online First: 2020/03/03]

58. Ruan Q, Yang K, Wang W, et al. Clinical predictors of mortality due to COVID-19 based on an analysis of data of 150 patients from Wuhan, China. Intensive Care Med 2020 doi: 10.1007/s00134-020-05991-X

59. Wan S, Xiang Y, Fang W, et al. Clinical features and treatment of COVID-19 patients in northeast Chongqing. J Med Virol 2020 doi: 10.1002/jmv.25783 [published Online First: 2020/03/22]

60. Wang D, Hu B, Hu C, et al. Clinical Characteristics of 138 Hospitalized Patients With 2019 Novel Coronavirus-Infected Pneumonia in Wuhan, China. JAMA 2020 doi: 10.1001/jama.2020.1585 [published Online First: 2020/02/08]

61. Zhang JJ, Dong X, Cao YY, et al. Clinical characteristics of 140 patients infected with SARS-CoV2 in Wuhan, China. Allergy 2020 doi: 10.1111/all.14238 [published Online First: 2020/02/23]

62. Mo P, Xing Y, Xiao Y, et al. Clinical characteristics of refractory COVID-19 pneumonia in Wuhan, China. Clin Infect Dis 2020 doi: 10.1093/cid/ciaa270 [published Online First: 2020/03/17]

63. Tang N, Li D, Wang X, et al. Abnormal coagulation parameters are associated with poor prognosis in patients with novel coronavirus pneumonia. J Thromb Haemost 2020;18(4):844-47. doi: 10.1111/jth.14768 [published Online First: 2020/02/20]

64. Wu C, Chen X, Cai Y, et al. Risk Factors Associated With Acute Respiratory Distress Syndrome and Death in Patients With Coronavirus Disease 2019 Pneumonia in Wuhan, China. JAMA Intern Med 2020 doi: 10.1001/jamainternmed.2020.0994 [published Online First: 2020/03/14]

65. Tian S, Hu N, Lou J, et al. Characteristics of COVID-19 infection in Beijing. J Infect 2020;80(4):401-06. doi: 10.1016/j.jinf.2020.02.018 [published Online First: 2020/03/01]

66. Qin C, Zhou L, Hu Z, et al. Dysregulation of immune response in patients with COVID-19 in Wuhan, China. Clin Infect Dis 2020 doi: 10.1093/cid/ciaa248 [published Online First: 2020/03/13] 
medRxiv preprint doi: https://doi.org/10.1101/2020.04.23.20076653; this version posted April 27, 2020. The copyright holder for this preprint (which was not certified by peer review) is the author/funder, who has granted medRxiv a license to display the preprint in perpetuity. It is made available under a CC-BY-NC-ND 4.0 International license.

67. Cheng Y, Luo R, Wang K, et al. Kidney disease is associated with in-hospital death of patients with COVID-19. Kidney International 2020 doi: 10.1016/j.kint.2020.03.005

68. Tang N, Bai H, Chen X, et al. Anticoagulant treatment is associated with decreased mortality in severe coronavirus disease 2019 patients with coagulopathy. J Thromb Haemost 2020 doi: $10.1111 /$ jth. 14817

69. Wu J, Li W, Shi X, et al. Early antiviral treatment contributes to alleviate the severity and improve the prognosis of patients with novel coronavirus disease (COVID-19). J Intern Med 2020 doi: 10.1111/joim.13063 [published Online First: 2020/03/29]

70. Wan Y, Li J, Shen L, et al. Enteric involvement in hospitalised patients with COVID-19 outside Wuhan. Lancet Gastroenterol Hepatol 2020 doi: 10.1016/S2468-1253(20)30118-7 [published Online First: 2020/04/19]

71. Gao L, Jiang D, Wen XS, et al. Prognostic value of NT-proBNP in patients with severe COVID-19. Respir Res 2020;21(1):83. doi: 10.1186/s12931-020-01352-w [published Online First: 2020/04/16]

72. Zheng F, Tang W, Li H, et al. Clinical characteristics of 161 cases of corona virus disease 2019 (COVID-19) in Changsha. Eur Rev Med Pharmacol Sci 2020;24(6):3404-10. doi: 10.26355/eurrev_202003_20711 [published Online First: 2020/04/10]

73. Cai Q, Huang D, Yu H, et al. Characteristics of Liver Tests in COVID-19 Patients. J Hepatol 2020 doi: 10.1016/j.jhep.2020.04.006 [published Online First: 2020/04/17]

74. Du RH, Liang LR, Yang CQ, et al. Predictors of Mortality for Patients with COVID-19 Pneumonia Caused by SARS-CoV-2: A Prospective Cohort Study. Eur Respir J 2020 doi: 10.1183/13993003.00524-2020 [published Online First: 2020/04/10]

75. Chen T, Dai Z, Mo P, et al. Clinical characteristics and outcomes of older patients with coronavirus disease 2019 (COVID-19) in Wuhan, China (2019): a single-centered, retrospective study. $J$ Gerontol A Biol Sci Med Sci 2020 doi: 10.1093/gerona/glaa089 [published Online First: 2020/04/13]

76. Feng Y, Ling Y, Bai T, et al. COVID-19 with Different Severity: A Multi-center Study of Clinical Features. Am J Respir Crit Care Med 2020 doi: 10.1164/rccm.202002-0445OC [published Online First: 2020/04/11]

77. He R, Lu Z, Zhang L, et al. The clinical course and its correlated immune status in COVID-19 pneumonia. Journal of Clinical Virology 2020 doi: 10.1016/j.jcv.2020.104361

78. Ji D, Zhang D, Xu J, et al. Prediction for Progression Risk in Patients with COVID-19 Pneumonia: the CALL Score. Clin Infect Dis 2020 doi: 10.1093/cid/ciaa414 [published Online First: 2020/04/10]

79. Li X, Xu S, Yu M, et al. Risk factors for severity and mortality in adult COVID-19 inpatients in Wuhan. J Allergy Clin Immunol 2020 doi: 10.1016/j.jaci.2020.04.006 [published Online First: 2020/04/16]

80. C C, JT Y, N Z, et al. Analysis of myocardial injury in patients with COVID-19 and association between concomitant cardiovascular diseases and severity of COVID-19. Chinese Medical Journal 2020;6(48) doi: 10.3760/cma.j.cn112148-20200225-00123

81. Wang X, Fang J, Zhu Y, et al. Clinical characteristics of non-critically ill patients with novel coronavirus infection (COVID-19) in a Fangcang Hospital. Clin Microbiol Infect 2020 doi: 10.1016/j.cmi.2020.03.032 [published Online First: 2020/04/07]

82. Zhou Y, Zhang Z, Tian J, et al. Risk factors associated with disease progression in a cohort of patients infected with the 2019 novel coronavirus. Ann Palliat Med 2020 doi: 10.21037/apm.2020.03.26 [published Online First: 2020/04/03] 
medRxiv preprint doi: https://doi.org/10.1101/2020.04.23.20076653; this version posted April 27, 2020. The copyright holder for this preprint (which was not certified by peer review) is the author/funder, who has granted medRxiv a license to display the preprint in perpetuity. It is made available under a CC-BY-NC-ND 4.0 International license.

83. Cao J, Tu WJ, Cheng W, et al. Clinical Features and Short-term Outcomes of 102 Patients with Corona Virus Disease 2019 in Wuhan, China. Clin Infect Dis 2020 doi: 10.1093/cid/ciaa243 [published Online First: 2020/04/03]

84. Chu J, Yang N, Wei Y, et al. Clinical characteristics of 54 medical staff with COVID-19: A retrospective study in a single center in Wuhan, China. J Med Virol 2020 doi: 10.1002/jmv.25793 [published Online First: 2020/03/31]

85. Li Y-K, Peng S, Li L-Q, et al. Clinical and Transmission Characteristics of Covid-19 , Äî A Retrospective Study of 25 Cases from a Single Thoracic Surgery Department. Curr Med Sci 2020;30:1-6. doi: 10.1007/s11596-020-2176-2

86. Al-Rousan N, Al-Najjar H. Data Analysis of Coronavirus CoVID-19 Epidemic in South Korea Based on Recovered and Death Cases. J Med Virol 2020 doi: 10.1002/jmv.25850 [published Online First: 2020/04/10]

87. Lighter J, Phillips M, Hochman S, et al. Obesity in patients younger than 60 years is a risk factor for Covid-19 hospital admission. Clinical Infectious Diseases 2020 doi: 10.1093/cid/ciaa415

88. Petrilli C, Jones S, Yang J, et al. Factors associated with hospitalization and critical illness among 4,103 patients with COVID-19 disease in New York City. 2020 doi: 10.1101/2020.04.08.20057794

89. Deng Q, Hu B, Zhang Y, et al. Suspected myocardial injury in patients with COVID-19: Evidence from front-line clinical observation in Wuhan, China. Int J Cardiol 2020 doi: 10.1016/j.ijcard.2020.03.087 [published Online First: 2020/04/16]

90. Lei S, Jiang F, Su W, et al. Clinical characteristics and outcomes of patients undergoing surgeries during the incubation period of COVID-19 infection. EClinicalMedicine 2020:100331. doi: 10.1016/j.eclinm.2020.100331 [published Online First: 2020/04/16]

91. Chen R, Liang W, Jiang M, et al. Risk factors of fatal outcome in hospitalized subjects with coronavirus disease 2019 from a nationwide analysis in China. Chest 2020 doi: 10.1016/j.chest.2020.04.010 [published Online First: 2020/04/19]

92. Wang L, He WB, Yu XM, et al. [Prognostic value of myocardial injury in patients with COVID19]. Zhonghua Yan Ke Za Zhi 2020;56(0):E009. doi: 10.3760/cma.j.cn112148-2020031300202 [published Online First: 2020/04/15]

93. Qian ZP, Mei X, Zhang YY, et al. [Analysis of baseline liver biochemical parameters in 324 cases with novel coronavirus pneumonia in Shanghai area]. Zhonghua Gan Zang Bing Za Zhi 2020;28(0):E005. doi: 10.3760/cma.j.cn501113-20200229-00076 [published Online First: 2020/04/10]

94. Simonnet A, Chetboun M, Poissy J, et al. High prevalence of obesity in severe acute respiratory syndrome coronavirus-2 (SARS-CoV-2) requiring invasive mechanical ventilation. Obesity (Silver Spring) 2020 doi: 10.1002/oby.22831 [published Online First: 2020/04/10]

95. Grasselli G, Zangrillo A, Zanella A, et al. Baseline Characteristics and Outcomes of 1591 Patients Infected With SARS-CoV-2 Admitted to ICUs of the Lombardy Region, Italy. JAMA 2020 doi: 10.1001/jama.2020.5394 [published Online First: 2020/04/07]

96. Yun L, Lin Y, Qian Z, et al. Clinical analysis on risk factors for COVID-19 patients becoming severe patients. Chinese Journal of Infectious Diseases 2020;38 doi: 10.3760/cma.j.cn31136520200211-00055

97. Niu S, Tian S, Lou J, et al. Clinical Characteristics of Older Patients Infected with COVID-19: A Descriptive Study. Archives of Gerontology and Geriatrics 2020 doi: 10.1016/j.archger.2020.104058

98. Interpretation of pneumonia diagnosis and treatment plan for new coronavirus infection (trial version 5): National Health Commission of the People's Republic of China [Available from: http://bgs.satcm.gov.cn/zhengcewenjian/2020-02-06/12848.html. 
medRxiv preprint doi: https://doi.org/10.1101/2020.04.23.20076653; this version posted April 27, 2020. The copyright holder for this preprint (which was not certified by peer review) is the author/funder, who has granted medRxiv a license to display the preprint in perpetuity. It is made available under a CC-BY-NC-ND 4.0 International license.

\section{Figure 1: PRISMA flow diagram}

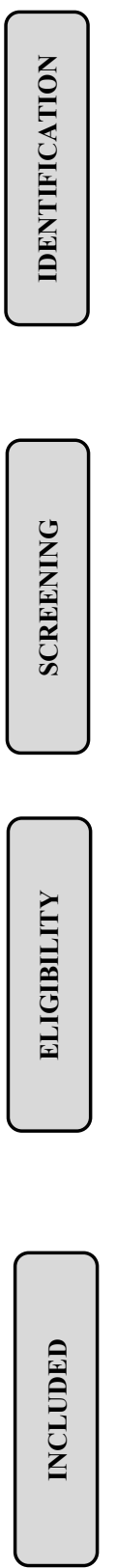

Records identified in reference lists

$$
(\mathrm{n}=31)
$$

$$
\begin{aligned}
& (n=6202) \\
& (n=0)
\end{aligned}
$$

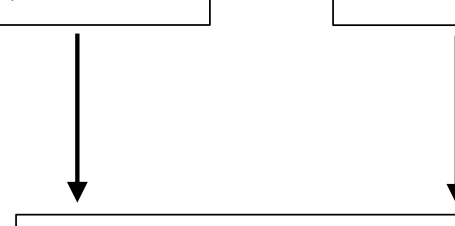

Records after duplicates removed $(\mathrm{n}=5770)$

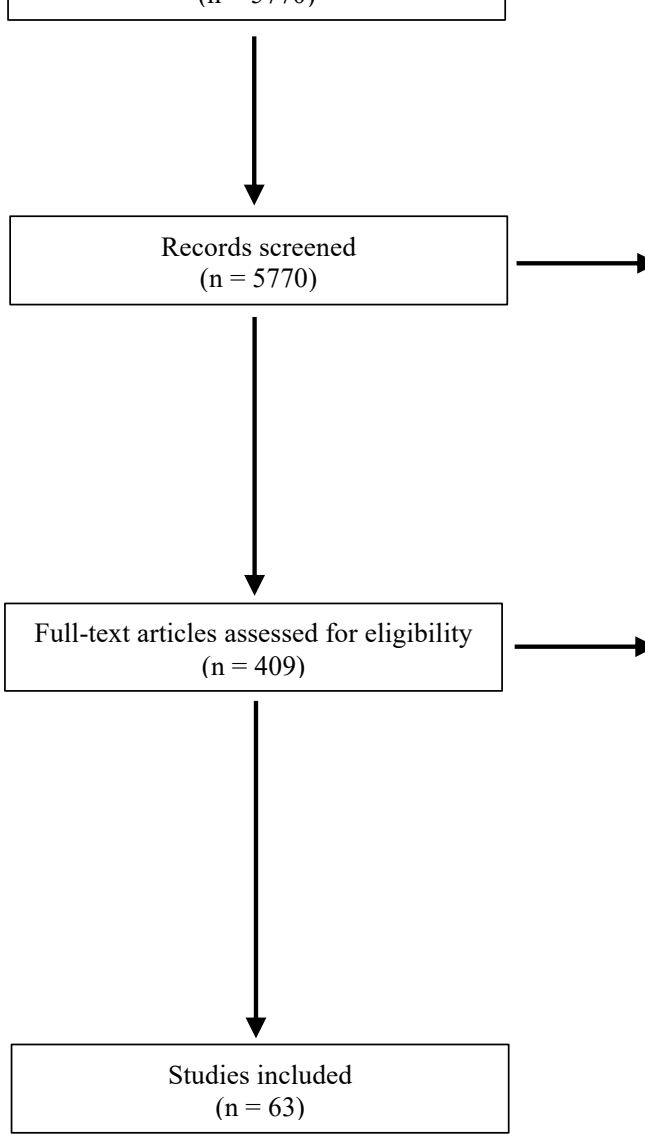

Records excluded on screening $(\mathrm{n}=5361)$ 
Table 1. Study characteristics

\begin{tabular}{|c|c|c|c|c|c|c|c|c|c|c|c|c|}
\hline Title & $\begin{array}{c}\text { First } \\
\text { author }\end{array}$ & Year & GRADE* & Location & Design & Population & $\begin{array}{l}\text { Gender } \\
(\% \\
\text { male })\end{array}$ & $\begin{array}{l}\text { Median } \\
\text { age }\end{array}$ & $\begin{array}{l}\text { No. } \\
\text { severe } \\
\text { cases }\end{array}$ & $\begin{array}{c}\text { Definition of severe } \\
\text { illness }\end{array}$ & $\begin{array}{l}\text { No. } \\
\text { variables } \\
\text { reported } \\
\text { on** (n) }\end{array}$ & $\begin{array}{c}\text { No. } \\
\text { variables } \\
\text { reported } \\
\text { as signifi- } \\
\text { cant** } \\
(\mathbf{n}) \\
\end{array}$ \\
\hline $\begin{array}{l}\text { Clinical features of patients } \\
\text { infected with } 2019 \text { novel } \\
\text { coronavirus in Wuhan, China }{ }^{40}\end{array}$ & Huang & 2020 & $\begin{array}{l}\text { Low } \\
\text { quality }\end{array}$ & $\begin{array}{l}\text { Wuhan, } \\
\text { China }\end{array}$ & $\begin{array}{l}\text { Prospective } \\
\text { cohort }\end{array}$ & $\begin{array}{l}41 \text { adult patients with nCoV-19 } \\
\text { admitted to a designated } \\
\text { Wuhan Hospital from 16/12/19 } \\
-2 / 1 / 20\end{array}$ & 73 & 49 & 13 & ICU admission & 42 & 16 \\
\hline $\begin{array}{l}\text { Clinical characteristics and } \\
\text { outcomes of } 112 \\
\text { cardiovascular disease patients } \\
\text { infected by } 2019-\mathrm{nCoV}^{41}\end{array}$ & Peng & 2020 & $\begin{array}{l}\text { Low } \\
\text { quality }\end{array}$ & $\begin{array}{l}\text { Wuhan, } \\
\text { China }\end{array}$ & $\begin{array}{l}\text { Retrospective } \\
\text { cohort }\end{array}$ & $\begin{array}{l}112 \text { adult patients with nCoV- } \\
19 \text { combined with CVD } \\
\text { admitted to Western Hospital } \\
\text { of Wuhan Medical College } \\
\text { from } 20 / 1 / 2020-15 / 2 / 2020\end{array}$ & 47 & 62 & 16 & NHC - critical & 30 & 6 \\
\hline $\begin{array}{l}\text { Clinical and biochemical } \\
\text { indexes from 2019-nCoV } \\
\text { infected patients linked to viral } \\
\text { loads and lung injury }{ }^{42}\end{array}$ & Liu & 2020 & $\begin{array}{l}\text { Low } \\
\text { quality }\end{array}$ & $\begin{array}{l}\text { Shenzhen, } \\
\text { China }\end{array}$ & $\begin{array}{l}\text { Retrospective } \\
\text { cohort }\end{array}$ & $\begin{array}{c}12 \text { patients with nCoV-19 } \\
\text { admitted to in Shenzhen Third } \\
\text { People's Hospital through } \\
\text { 21/1/20 }\end{array}$ & 67 & 62 & 8 & $\begin{array}{c}\text { NHC - severe \& } \\
\text { critical }\end{array}$ & 8 & 8 \\
\hline $\begin{array}{l}\text { Elevated exhaustion levels and } \\
\text { reduced functional diversity of } \\
\mathrm{T} \text { cells in peripheral blood may } \\
\text { predict severe progression in } \\
\text { COVID-19 patients }\end{array}$ & Zheng & 2020 & $\begin{array}{l}\text { Low } \\
\text { quality }\end{array}$ & $\begin{array}{l}\text { Kunming, } \\
\text { China }\end{array}$ & $\begin{array}{l}\text { Retrospective } \\
\text { cohort }\end{array}$ & $\begin{array}{c}16 \text { patients with } \mathrm{nCoV}-19 \\
\text { admitted to Yunnan Provincial } \\
\text { Hospital of ID }\end{array}$ & 56 & $\begin{array}{c}\text { Not } \\
\text { reported }\end{array}$ & 6 & $\begin{array}{l}\text { No specific definition } \\
\text { of severity provided }\end{array}$ & 7 & 5 \\
\hline $\begin{array}{c}\text { Analysis of clinical } \\
\text { characteristics of } 29 \text { cases of } \\
\text { new type coronavirus } \\
\text { pneumonia }{ }^{44}\end{array}$ & Chen & 2020 & $\begin{array}{l}\text { Low } \\
\text { quality }\end{array}$ & $\begin{array}{l}\text { Wuhan, } \\
\text { China }\end{array}$ & $\begin{array}{l}\text { Retrospective } \\
\text { cohort }\end{array}$ & $\begin{array}{c}29 \text { patients with nCoV-19 } \\
\text { admitted to Tongji Hospital in } \\
\text { January } 2020\end{array}$ & 72 & 56 & 14 & $\begin{array}{c}\text { NHC - severe \& } \\
\text { critical }\end{array}$ & 9 & 2 \\
\hline $\begin{array}{c}\text { Analysis of clinical } \\
\text { characteristics of } 30 \text { cases of } \\
\text { new coronavirus } \\
\text { pneumonia in medical staff } \\
\end{array}$ & Liu & 2020 & $\begin{array}{l}\text { Low } \\
\text { quality }\end{array}$ & $\begin{array}{l}\text { Wuhan, } \\
\text { China }\end{array}$ & $\begin{array}{l}\text { Retrospective } \\
\text { cohort }\end{array}$ & $\begin{array}{c}30 \text { adult hospital staff workers } \\
\text { with nCoV-19 admitted to } \\
\text { Jianghan Hospital from } \\
\text { 10/1/20-3/10/2020 }\end{array}$ & 50 & 35 & 4 & $\begin{array}{c}\text { NHC - severe \& } \\
\text { critical }\end{array}$ & 8 & 8 \\
\hline $\begin{array}{l}\text { The clinical characteristics of } \\
\text { myocardial injury in severe and } \\
\text { very severe patients with } 2019 \\
\text { Novel Coronavirus Disease }^{46}\end{array}$ & Zhou & 2020 & $\begin{array}{l}\text { Low } \\
\text { quality }\end{array}$ & $\begin{array}{l}\text { Wuhan, } \\
\text { China }\end{array}$ & $\begin{array}{l}\text { Retrospective } \\
\text { cohort }\end{array}$ & $\begin{array}{l}34 \text { patients with nCoV-19 } \\
\text { admitted to Tongji Medical } \\
\text { College from 5/2/20-13/2/20 }\end{array}$ & 46 & 50 & 8 & $\mathrm{NHC}$ - critical & 11 & 3 \\
\hline $\begin{array}{l}\text { Diagnostic utility of clinical } \\
\text { laboratory data determinations } \\
\text { for patients with the severe } \\
\text { COVID- } 19^{47}\end{array}$ & Gao & 2020 & $\begin{array}{l}\text { Low } \\
\text { quality }\end{array}$ & $\begin{array}{l}\text { Fuyang, } \\
\text { China }\end{array}$ & $\begin{array}{l}\text { Retrospective } \\
\text { cohort }\end{array}$ & $\begin{array}{l}43 \text { adult patients with } \mathrm{nCoV}-19 \\
\text { at Fuyang Second People's } \\
\text { hospital from } 23 / 1 / 20-2 / 2 / 20\end{array}$ & 60 & 44 & 15 & $\begin{array}{c}\text { NHC - severe \& } \\
\text { critical }\end{array}$ & 25 & 8 \\
\hline
\end{tabular}




\begin{tabular}{|c|c|c|c|c|c|c|c|c|c|c|c|c|}
\hline $\begin{array}{l}\text { Quantitative computed } \\
\text { tomography analysis for } \\
\text { stratifying the severity of } \\
\text { Coronavirus Disease } 2019^{48}\end{array}$ & Shen & 2020 & $\begin{array}{l}\text { Low } \\
\text { quality }\end{array}$ & China & $\begin{array}{l}\text { Retrospective } \\
\text { cohort }\end{array}$ & $\begin{array}{l}44 \text { adult patients with nCoV-19 } \\
\text { with CT images from } 22 / 1 / 20 \text { - } \\
7 / 2 / 20\end{array}$ & 47 & $\begin{array}{l}\text { Not } \\
\text { reported }\end{array}$ & 9 & $\begin{array}{c}\text { NHC - severe \& } \\
\text { critical }\end{array}$ & 2 & 1 \\
\hline $\begin{array}{l}\text { Relation between chest CT } \\
\text { findings and clinical conditions } \\
\text { of Coronavirus Disease } \\
\text { (COVID-19) pneumonia: A } \\
\text { multicenter study }{ }^{49}\end{array}$ & Zhao & 2020 & $\begin{array}{l}\text { Low } \\
\text { quality }\end{array}$ & $\begin{array}{l}\text { Hunan, } \\
\text { China }\end{array}$ & $\begin{array}{l}\text { Retrospective } \\
\text { cohort }\end{array}$ & $\begin{array}{l}101 \text { adult patients with nCoV- } \\
19 \text { pneumonia from four } \\
\text { institutions in Hunan }\end{array}$ & 55 & 43 & 14 & $\begin{array}{l}\text { NHC - severe \& } \\
\text { critical }\end{array}$ & 4 & 2 \\
\hline $\begin{array}{l}\text { Cancer patients in SARS-CoV- } \\
2 \text { infection: a nationwide } \\
\text { analysis in China }\end{array}$ & Liang & 2020 & $\begin{array}{l}\text { Low } \\
\text { quality }\end{array}$ & China & $\begin{array}{l}\text { Prospective } \\
\text { cohort }\end{array}$ & $\begin{array}{c}1,590 \text { adult patients with } \\
\text { nCoV-19 acute respiratory } \\
\text { disease admitted to a hospital } \\
\text { in China }\end{array}$ & $\begin{array}{l}\text { Not } \\
\text { reported }\end{array}$ & $\begin{array}{l}\text { Not } \\
\text { reported }\end{array}$ & 131 & $\begin{array}{l}\text { ICU admission, mech } \\
\text { ventilation, mortality }\end{array}$ & 1 & 1 \\
\hline $\begin{array}{c}\text { Association of radiologic } \\
\text { findings with mortality of } \\
\text { patients infected with } 2019 \\
\text { novel coronavirus in Wuhan, } \\
\text { China }^{51}\end{array}$ & Yuan & 2020 & $\begin{array}{l}\text { Low } \\
\text { quality }\end{array}$ & $\begin{array}{l}\text { Wuhan, } \\
\text { China }\end{array}$ & $\begin{array}{l}\text { Retrospective } \\
\text { cohort }\end{array}$ & $\begin{array}{l}27 \text { consecutive adult patients } \\
\text { with nCoV-19 admitted to } \\
\text { Central Hospital of Wuhan }\end{array}$ & 44 & 60 & 10 & Mortality & 13 & 6 \\
\hline $\begin{array}{c}\text { Neutrophil-to-lymphocyte ratio } \\
\text { predicts severe illness patients } \\
\text { with } 2019 \text { Novel Coronavirus } \\
\text { in the early stage }\end{array}$ & Jingyuan & 2020 & $\begin{array}{l}\text { Low } \\
\text { quality }\end{array}$ & $\begin{array}{l}\text { Beijing, } \\
\text { China }\end{array}$ & $\begin{array}{l}\text { Prospective } \\
\text { cohort }\end{array}$ & $\begin{array}{c}61 \text { adult patients with nCoV-19 } \\
\text { infection treated at Beijing } \\
\text { Ditan Hospital from 13/1/20- } \\
31 / 1 / 20\end{array}$ & 51 & 40 & 17 & $\begin{array}{c}\text { NHC - severe \& } \\
\text { critical }\end{array}$ & 35 & 8 \\
\hline $\begin{array}{l}\text { Clinical features of } 69 \text { cases } \\
\text { with Coronavirus Disease } 2019 \\
\text { in Wuhan, China }{ }^{53}\end{array}$ & Wang & 2020 & $\begin{array}{l}\text { Low } \\
\text { quality }\end{array}$ & $\begin{array}{l}\text { Wuhan, } \\
\text { China }\end{array}$ & $\begin{array}{l}\text { Retrospective } \\
\quad \text { cohort }\end{array}$ & $\begin{array}{l}69 \text { adult patients with nCoV-19 } \\
\text { hospitalized in Union Hospital } \\
\text { from } 16 / 1 / 20-29 / 1 / 20\end{array}$ & 46 & 42 & 55 & $\begin{array}{c}\text { Oxygen requirement } \\
<90 \%\end{array}$ & 35 & 13 \\
\hline $\begin{array}{l}\text { Hematologic parameters in } \\
\text { patients with COVID-19 } \\
\text { infection }\end{array}$ & Fan & 2020 & $\begin{array}{l}\text { Low } \\
\text { quality }\end{array}$ & Singapore & $\begin{array}{l}\text { Retrospective } \\
\text { cohort }\end{array}$ & $\begin{array}{l}69 \text { adult patients with } \mathrm{nCoV}-19 \\
\text { treated at the National Centre } \\
\text { for Infectious Diseases in } \\
\text { Singapore through } 28 / 2 / 20\end{array}$ & 55 & 41 & 9 & ICU admission & 10 & 3 \\
\hline $\begin{array}{l}\text { Analysis of factors associated } \\
\text { with disease outcomes in } \\
\text { hospitalized patients with } 2019 \\
\text { novel coronavirus disease }^{55}\end{array}$ & Liu & 2020 & $\begin{array}{l}\text { Low } \\
\text { quality }\end{array}$ & $\begin{array}{l}\text { Wuhan, } \\
\text { China }\end{array}$ & $\begin{array}{l}\text { Retrospective } \\
\text { cohort }\end{array}$ & $\begin{array}{c}78 \text { adult patients with nCoV-19 } \\
\text { admitted to three tertiary } \\
\text { hospitals in Wuhan from } \\
30 / 12 / 19-15 / 1 / 20\end{array}$ & 50 & 38 & 8 & $\begin{array}{l}\text { Progression in disease } \\
\text { state from common to } \\
\text { severe, severe to } \\
\text { critical or critical to } \\
\text { death as defined by } \\
\text { NHC }\end{array}$ & 26 & 5 \\
\hline $\begin{array}{l}\text { Clinical features and short-term } \\
\text { outcomes of } 18 \text { patients with } \\
\text { corona virus disease } 2019 \text { in } \\
\text { intensive care unit }{ }^{56}\end{array}$ & Cao & 2020 & $\begin{array}{l}\text { Low } \\
\text { quality }\end{array}$ & $\begin{array}{l}\text { Wuhan, } \\
\text { China }\end{array}$ & $\begin{array}{l}\text { Retrospective } \\
\text { case series }\end{array}$ & $\begin{array}{l}102 \text { adult patients with } \mathrm{nCoV}- \\
19 \text { admitted to Wuhan } \\
\text { University Zhongnan Hospital } \\
\text { from 3/1/20-1/2/20 }\end{array}$ & 51 & 54 & 18 & ICU admission & 19 & 3 \\
\hline
\end{tabular}




\begin{tabular}{|c|c|c|c|c|c|c|c|c|c|c|c|c|}
\hline $\begin{array}{l}\text { The clinical and Chest CT } \\
\text { features associated with severe } \\
\text { and critical COVID-19 } \\
\text { pneumonia }^{57}\end{array}$ & $\mathrm{Li}$ & 2020 & $\begin{array}{l}\text { Low } \\
\text { quality }\end{array}$ & $\begin{array}{c}\text { Chongqin } \\
\text { g, China }\end{array}$ & $\begin{array}{l}\text { Retrospective } \\
\text { cohort }\end{array}$ & $\begin{array}{c}83 \text { adult patients with } \mathrm{nCoV}-19 \\
\text { and abnormal findings on CT } \\
\text { in Chongqing Medical } \\
\text { University affiliated hospitals } \\
\text { from } 1 / 1 / 20-29 / 2 / 20\end{array}$ & 53 & 45.5 & 25 & $\begin{array}{c}\text { NHC - severe \& } \\
\text { critical }\end{array}$ & 34 & 14 \\
\hline $\begin{array}{l}\text { Clinical predictors of mortality } \\
\text { due to COVID-19 based on an } \\
\text { analysis of data of } 150 \text { patients } \\
\text { from Wuhan, China }{ }^{58}\end{array}$ & Ruan & 2020 & $\begin{array}{l}\text { Low } \\
\text { quality }\end{array}$ & $\begin{array}{l}\text { Wuhan, } \\
\text { China }\end{array}$ & $\begin{array}{l}\text { Retrospective } \\
\text { cohort }\end{array}$ & $\begin{array}{l}150 \text { adult patients with } \mathrm{nCoV}- \\
19 \text { at Jinyintan and Tongji } \\
\text { Hospitals }\end{array}$ & 72 & 57 & 68 & Mortality & 34 & 16 \\
\hline $\begin{array}{l}\text { Clinical features and treatment } \\
\text { of COVID-19 patients in } \\
\text { Northeast Chongqing }\end{array}$ & Wan & 2020 & $\begin{array}{l}\text { Low } \\
\text { quality }\end{array}$ & $\begin{array}{c}\text { Chongqin } \\
\text { g, China }\end{array}$ & $\begin{array}{l}\text { Retrospective } \\
\text { cohort }\end{array}$ & $\begin{array}{l}135 \text { adult patients with nCoV- } \\
19 \text { hospitalized in Chongqing } \\
\text { University Three Gorges } \\
\text { Hospital from } 23 / 1 / 20-8 / 2 / 20\end{array}$ & 53 & 47 & 40 & $\begin{array}{c}\text { NHC - severe \& } \\
\text { critical }\end{array}$ & 17 & 15 \\
\hline $\begin{array}{l}\text { Clinical characteristics of } 138 \\
\text { hospitalized patients with } 2019 \\
\text { novel coronavirus-infected } \\
\text { pneumonia in Wuhan, China }\end{array}$ & Wang & 2020 & $\begin{array}{l}\text { Low } \\
\text { quality }\end{array}$ & $\begin{array}{l}\text { Wuhan, } \\
\text { China }\end{array}$ & $\begin{array}{l}\text { Retrospective } \\
\text { case series }\end{array}$ & $\begin{array}{l}138 \text { consecutive adult patients } \\
\text { with nCoV-19 hospitalized in } \\
\text { Zhongnan Hospital of Wuhan } \\
\text { University from 1/1-28/1/20 }\end{array}$ & 54.3 & 56 & 36 & ICU admission & 42 & 22 \\
\hline $\begin{array}{l}\text { Clinical characteristics of } 140 \\
\text { patients infected by SARS- } \\
\text { CoV-2 in Wuhan, China }{ }^{61}\end{array}$ & Zhang & 2020 & $\begin{array}{l}\text { Low } \\
\text { quality }\end{array}$ & $\begin{array}{l}\text { Wuhan, } \\
\text { China }\end{array}$ & $\begin{array}{l}\text { Retrospective } \\
\text { cohort }\end{array}$ & $\begin{array}{l}140 \text { adult patients with } \mathrm{nCoV}- \\
19 \text { infection No. } 7 \text { Hospital of } \\
\text { Wuhan from } 16 / 1 / 20-3 / 2 / 20\end{array}$ & 50.7 & 57 & 59 & NHC - severe & 20 & 2 \\
\hline $\begin{array}{l}\text { Clinical characteristics of } \\
\text { refractory COVID-19 } \\
\text { pneumonia in Wuhan, China }\end{array}$ & Pingzheng & 2020 & $\begin{array}{l}\text { Low } \\
\text { quality }\end{array}$ & $\begin{array}{l}\text { Wuhan, } \\
\text { China }\end{array}$ & $\begin{array}{l}\text { Retrospective } \\
\text { cohort }\end{array}$ & $\begin{array}{l}155 \text { consecutive adult patients } \\
\text { with nCoV-19 infection at } \\
\text { Zhongnan Hospital of Wuhan } \\
\text { Universityfrom 1/1/20-5/2/20 }\end{array}$ & 55.5 & 54 & 85 & Hospital stay $<10$ days & 15 & 12 \\
\hline $\begin{array}{l}\text { Abnormal coagulation } \\
\text { parameters are associated with } \\
\text { poor prognosis in patients with } \\
\text { novel coronavirus pneumonia }\end{array}$ & Tang & 2020 & $\begin{array}{l}\text { Low } \\
\text { quality }\end{array}$ & $\begin{array}{l}\text { Wuhan, } \\
\text { China }\end{array}$ & $\begin{array}{l}\text { Retrospective } \\
\text { cohort }\end{array}$ & $\begin{array}{c}183 \text { adult patients with } \mathrm{nCoV}- \\
19 \text { infection at Tongji Hospital } \\
1 / 1 / 20-3 / 2 / 20\end{array}$ & 53.6 & 54.1 & 21 & Mortality & 9 & 5 \\
\hline $\begin{array}{c}\text { Clinical course and risk factors } \\
\text { for mortality of adult inpatients } \\
\text { with COVID-19 in Wuhan, } \\
\text { China: a retrospective cohort } \\
\text { study }^{39}\end{array}$ & Zhou & 2020 & $\begin{array}{l}\text { Low } \\
\text { quality }\end{array}$ & $\begin{array}{l}\text { Wuhan, } \\
\text { China }\end{array}$ & $\begin{array}{l}\text { Retrospective } \\
\text { cohort }\end{array}$ & $\begin{array}{l}191 \text { patients with nCoV-19 } \\
\text { infection at Jinyintan Hospital } \\
\text { and Wuhan Pulmonary } \\
\text { Hospital through 20/1/20 }\end{array}$ & 62 & 56 & 54 & Mortality & 37 & 24 \\
\hline $\begin{array}{l}\text { Risk factors associated with } \\
\text { Acute Respiratory Distress } \\
\text { Syndrome and death in patients } \\
\text { with Coronavirus Disease } 2019 \\
\text { pneumonia in Wuhan, China }{ }^{64}\end{array}$ & $\mathrm{Wu}$ & 2020 & $\begin{array}{l}\text { Low } \\
\text { quality }\end{array}$ & $\begin{array}{l}\text { Wuhan, } \\
\text { China }\end{array}$ & $\begin{array}{l}\text { Retrospective } \\
\text { cohort }\end{array}$ & $\begin{array}{l}201 \text { adult patients with } \mathrm{nCoV} \text { - } \\
19 \text { infection at Wuhan } \\
\text { Jinyintan Hospital from } \\
25 / 12 / 19-26 / 1 / 20\end{array}$ & 63.7 & 51 & 84 & $\begin{array}{l}\text { Development of Acute } \\
\text { Respiratory Distress } \\
\text { Syndrome }\end{array}$ & 34 & 23 \\
\hline $\begin{array}{c}\text { Clinical progression of patients } \\
\text { with COVID-19 in Shanghai, } \\
\text { China }{ }^{30}\end{array}$ & Chen & 2020 & $\begin{array}{l}\text { Low } \\
\text { quality }\end{array}$ & $\begin{array}{c}\text { Shanghai, } \\
\text { China }\end{array}$ & $\begin{array}{l}\text { Retrospective } \\
\text { cohort }\end{array}$ & $\begin{array}{c}249 \text { adult patients with } \mathrm{nCoV}- \\
19 \text { at Shanghai Public Health } \\
\text { Clinical Center from 20/1/20- } \\
6 / 2 / 20\end{array}$ & 50.6 & 51 & 22 & ICU admission & 13 & 1 \\
\hline
\end{tabular}




\begin{tabular}{|c|c|c|c|c|c|c|c|c|c|c|c|c|}
\hline $\begin{array}{l}\text { Characteristics of COVID-19 } \\
\text { infection in Beijing }\end{array}$ & Tian & 2020 & $\begin{array}{l}\text { Low } \\
\text { quality }\end{array}$ & $\begin{array}{l}\text { Beijing, } \\
\text { China }\end{array}$ & $\begin{array}{l}\text { Retrospective } \\
\text { cohort }\end{array}$ & $\begin{array}{l}262 \text { adult patients with nCoV- } \\
19 \text { transferred to designated } \\
\text { COVID hospitals by Beijing } \\
\text { EMS from } 20 / 1 / 20-10 / 2 / 20\end{array}$ & 48.5 & 47.5 & 46 & $\begin{array}{l}\text { Dyspnea or respiratory } \\
\text { failure }\end{array}$ & 7 & 1 \\
\hline $\begin{array}{l}\text { Dysregulation of immune } \\
\text { response in patients with } \\
\text { COVID-19 in Wuhan, China }\end{array}$ & Chuan & 2020 & $\begin{array}{l}\text { Low } \\
\text { quality }\end{array}$ & $\begin{array}{l}\text { Wuhan, } \\
\text { China }\end{array}$ & $\begin{array}{l}\text { Retrospective } \\
\text { cohort }\end{array}$ & $\begin{array}{l}452 \text { adult patients with 2019- } \\
\text { nCoV infection at Tongji } \\
\text { Hospital from } 10 / 1 / 20-12 / 2 / 20\end{array}$ & 52 & 58 & 286 & $\mathrm{NHC}$ - severe & 55 & 23 \\
\hline $\begin{array}{l}\text { Host susceptibility to severe } \\
\text { COVID-19 and establishment } \\
\text { of a host risk score: findings of } \\
487 \text { cases outside Wuhan }{ }^{29}\end{array}$ & Shi & 2020 & $\begin{array}{l}\text { Low } \\
\text { quality }\end{array}$ & $\begin{array}{l}\text { Zheijang } \\
\text { Province, } \\
\text { China }\end{array}$ & $\begin{array}{l}\text { Retrospective } \\
\text { cohort }\end{array}$ & $\begin{array}{l}487 \text { adult patients with nCoV- } \\
19 \text { in Zhejiang Province } \\
\text { through } 11 / 2 / 20\end{array}$ & 53.2 & 46 & 49 & $\begin{array}{l}\text { Severe, "pneumonia } \\
\text { that can be } \\
\text { severe and } \\
\text { characterized by fever, } \\
\text { cough, dyspnea, } \\
\text { bilateral pulmonary } \\
\text { infiltrates, and acute } \\
\text { respiratory } \\
\text { injury" }\end{array}$ & 8 & 6 \\
\hline $\begin{array}{l}\text { Kidney disease is associated } \\
\text { with in-hospital death of } \\
\text { patients with COVID-1967 }\end{array}$ & Cheng & 2020 & $\begin{array}{l}\text { Moderate } \\
\text { quality }\end{array}$ & $\begin{array}{l}\text { Wuhan, } \\
\text { China }\end{array}$ & $\begin{array}{l}\text { Prospective } \\
\text { cohort }\end{array}$ & $\begin{array}{l}701 \text { adult patients with } \mathrm{nCoV}- \\
19 \text { infection treated at Tongji } \\
\text { Hospital from } 28 / 1 / 20-11 / 2 / 20\end{array}$ & 52 & 63 & 113 & Mortality & 17 & 11 \\
\hline $\begin{array}{l}\text { Anticoagulant treatment is } \\
\text { associated with decreased } \\
\text { mortality in severe coronavirus } \\
\text { disease } 2019 \text { patients with } \\
\text { coagulopathy } \\
\text { c8 }\end{array}$ & Tang & 2020 & $\begin{array}{l}\text { Low } \\
\text { quality }\end{array}$ & $\begin{array}{l}\text { Wuhan, } \\
\text { China }\end{array}$ & $\begin{array}{l}\text { Retrospective } \\
\text { cohort }\end{array}$ & $\begin{array}{c}449 \text { consecutive adult patients } \\
\text { with nCoV-19 infection treated } \\
\text { at Tongji Hospital from 1/1/20- } \\
13 / 2 / 20\end{array}$ & 59.7 & 65.1 & 134 & Mortality & 7 & 6 \\
\hline $\begin{array}{l}\text { Early antiviral treatment } \\
\text { contributes to alleviate the } \\
\text { severity and improve the } \\
\text { prognosis of patients with } \\
\text { novel coronavirus disease } \\
\text { (COVID-19) }\end{array}$ & $\mathrm{Wu}$ & 2020 & $\begin{array}{l}\text { Low } \\
\text { quality }\end{array}$ & $\begin{array}{l}\text { Jiangsu \& } \\
\text { Anhui } \\
\text { Provinces, } \\
\text { China }\end{array}$ & $\begin{array}{l}\text { Retrospective } \\
\text { cohort }\end{array}$ & $\begin{array}{l}280 \text { patients with nCoV-19 } \\
\text { infection treated at four } \\
\text { hospitals in the Jiangsu and } \\
\text { Anhui from } 20 / 1 / 20-19 / 2 / 20\end{array}$ & 53.93 & 43.12 & 83 & $\begin{array}{l}\text { NHC - severe \& } \\
\text { critical }\end{array}$ & 17 & 32 \\
\hline $\begin{array}{l}\text { Clinical features of COVID-19 } \\
\text { in elderly patients: A } \\
\text { comparison with young and } \\
\text { middle-aged patients }{ }^{28}\end{array}$ & Liu & 2020 & $\begin{array}{l}\text { Low } \\
\text { quality }\end{array}$ & $\begin{array}{l}\text { Hainan, } \\
\text { China }\end{array}$ & $\begin{array}{l}\text { Retrospective } \\
\text { cohort }\end{array}$ & $\begin{array}{l}56 \text { patients with nCoV-19 } \\
\text { infection treated at Hainan } \\
\text { Provincial People's Hospital } \\
\text { from } 15 / 1-18 / 2 / 20\end{array}$ & 55.4 & 53.75 & 6 & Mechanical ventilation & 1 & 1 \\
\hline $\begin{array}{c}\text { Enteric involvement in } \\
\text { hospitalised patients with } \\
\text { COVID-19 outside Wuhan }\end{array}$ & Wan & 2020 & $\begin{array}{l}\text { Low } \\
\text { quality }\end{array}$ & $\begin{array}{l}\text { Guangdon } \\
\text { g, Hubei, } \\
\text { and } \\
\text { Jiangxi } \\
\text { Provinces, } \\
\text { China } \\
\end{array}$ & $\begin{array}{l}\text { Retrospective } \\
\text { cohort }\end{array}$ & $\begin{array}{l}232 \text { adult patients with nCoV- } \\
19 \text { infection admitted to } 14 \\
\text { Chinese hospitals from } \\
19 / 1 / 2020-6 / 3 / 2020\end{array}$ & 55.6 & 47.5 & 61 & Vague severe & 1 & 1 \\
\hline
\end{tabular}




\begin{tabular}{|c|c|c|c|c|c|c|c|c|c|c|c|c|}
\hline $\begin{array}{l}\text { Prognostic value of NT- } \\
\text { proBNP in patients with severe } \\
\text { COVID-19 }\end{array}$ & Gao & 2020 & $\begin{array}{c}\text { Low } \\
\text { quality }\end{array}$ & $\begin{array}{l}\text { Wuhan, } \\
\text { China }\end{array}$ & $\begin{array}{l}\text { Retrospective } \\
\text { cohort }\end{array}$ & $\begin{array}{l}54 \text { consecutive adult patients } \\
\text { with severe nCoV-19 } \\
\text { pneumonia admitted to Hubei } \\
\text { General Hospital (n.d.). }\end{array}$ & 44.4 & 60.4 & 102 & Mortality & 1 & 1 \\
\hline $\begin{array}{l}\text { Clinical characteristics of } 161 \\
\text { cases of corona virus disease } \\
2019 \text { (COVID-19) in } \\
\text { Changsha }^{72}\end{array}$ & Zheng & 2020 & $\begin{array}{l}\text { Low } \\
\text { quality }\end{array}$ & $\begin{array}{l}\text { Hunan, } \\
\text { China }\end{array}$ & $\begin{array}{l}\text { Retrospective } \\
\text { cohort }\end{array}$ & $\begin{array}{l}161 \text { adult patients with nCoV- } \\
19 \text { infection admitted to the } \\
\text { North Hospital of Changsha } \\
\text { first Hospital (Changsha Public } \\
\text { Health treatment Center) from } \\
\text { 17/1/2020 - 7/2/2020 }\end{array}$ & 49.7 & 45 & 30 & Vague severe & 29 & 12 \\
\hline $\begin{array}{l}\text { Characteristics of Liver Tests } \\
\text { in COVID-19 Patients }\end{array}$ & Cai & 2020 & $\begin{array}{c}\text { Low } \\
\text { quality }\end{array}$ & $\begin{array}{l}\text { Shenzhen, } \\
\text { China }\end{array}$ & $\begin{array}{l}\text { Prospective } \\
\text { cohort }\end{array}$ & $\begin{array}{l}417 \text { adult patients with nCoV- } \\
19 \text { infection admitted to the } \\
\text { Third People's Hospital of } \\
\text { Shenzhen from } 11 / 1 / 2020 \text { - } \\
21 / 2 / 2020\end{array}$ & 47.5 & 47 & 91 & $\begin{array}{c}\text { NHC - severe \& } \\
\text { critical }\end{array}$ & 5 & 4 \\
\hline $\begin{array}{c}\text { Predictors of Mortality for } \\
\text { Patients with COVID-19 } \\
\text { Pneumonia Caused by SARS- } \\
\text { CoV-2: A Prospective Cohort } \\
\text { Study }^{74}\end{array}$ & $\mathrm{Du}$ & 2020 & $\begin{array}{c}\text { Low } \\
\text { quality }\end{array}$ & $\begin{array}{l}\text { Wuhan, } \\
\text { China }\end{array}$ & $\begin{array}{l}\text { Prospective } \\
\text { cohort }\end{array}$ & $\begin{array}{c}179 \text { consecutive adult patients } \\
\text { with nCoV-19 infection } \\
\text { admitted to Wuhan Pulmonary } \\
\text { Hospital from } 25 / 12 / 19 \text { - } \\
7 / 3 / 2020\end{array}$ & 54.2 & 57.6 & 21 & Mortality & 38 & 18 \\
\hline $\begin{array}{l}\text { Clinical characteristics and } \\
\text { outcomes of older patients with } \\
\text { coronavirus disease } 2019 \\
\text { (COVID-19) in Wuhan, China } \\
\text { (2019): a single-centered, } \\
\text { retrospective study }\end{array}$ & Chen & 2020 & $\begin{array}{l}\text { Low } \\
\text { quality }\end{array}$ & $\begin{array}{l}\text { Wuhan, } \\
\text { China }\end{array}$ & $\begin{array}{l}\text { Retrospective } \\
\text { cohort }\end{array}$ & $\begin{array}{l}203 \text { older adult patients with } \\
\text { nCoV-19 infection admitted to } \\
\text { Zhongnan Hospital of Wuhan } \\
\text { University from 01/1- } \\
\text { 10/02/2020 }\end{array}$ & 53.2 & 54 & 107 & $\begin{array}{c}\text { NHC - severe \& } \\
\text { critical }\end{array}$ & 1 & 1 \\
\hline $\begin{array}{l}\text { COVID-19 with Different } \\
\text { Severity: A Multi-center Study } \\
\text { of Clinical Features }{ }^{76}\end{array}$ & Feng & 2020 & $\begin{array}{c}\text { Low } \\
\text { quality }\end{array}$ & $\begin{array}{l}\text { Wuhan, } \\
\text { Shanghai } \\
\text { and Anhui } \\
\text { Provinces, }\end{array}$ & $\begin{array}{l}\text { Retrospective } \\
\text { cohort }\end{array}$ & $\begin{array}{c}476 \text { adult patients with } \mathrm{nCoV}- \\
19 \text { infection admitted to three } \\
\text { hospitals in China between } \\
01 / 1-15 / 02 / 2020\end{array}$ & 56.9 & 53 & 124 & $\begin{array}{c}\text { NHC - severe \& } \\
\text { critical }\end{array}$ & 46 & 32 \\
\hline $\begin{array}{l}\text { The clinical course and its } \\
\text { correlated immune status in } \\
\text { COVID-19 pneumonia }{ }^{77}\end{array}$ & $\mathrm{He}$ & 2020 & $\begin{array}{l}\text { Low } \\
\text { quality }\end{array}$ & $\begin{array}{l}\text { Wuhan, } \\
\text { China }\end{array}$ & $\begin{array}{l}\text { Retrospective } \\
\text { cohort }\end{array}$ & $\begin{array}{c}204 \text { adult patients with nCoV- } \\
19 \text { infection admitted to } \\
\text { Renmin Hospital of Wuhan } \\
\text { University between 10/1.- } \\
\text { 13/02/2020 }\end{array}$ & 38.7 & 49 & 69 & $\begin{array}{c}\text { NHC - severe \& } \\
\text { critical }\end{array}$ & 45 & 22 \\
\hline
\end{tabular}


Prediction for Progression Risk in Patients with COVID-19 Pneumonia: the CALL Score ${ }^{7}$

Risk factors for severity and mortality in adult COVID-19 inpatients in Wuhan ${ }^{79}$

Analysis of myocardial injury in patients with COVID-19 and association between concomitant cardiovascula diseases and severity of COVID-19 $9^{80}$

Clinical characteristics of noncritically ill patients with novel coronavirus infection (COVID19) in a Fangcang Hospital ${ }^{81}$
208 consecutive adult patients with $\mathrm{nCoV}-19$ infection

admitted to Fuyang Secon

People's Hospital or Fifth

Medical Center of Chinese

PLA General Hospital between 20/01-22/02/2020

548 adult patients with $\mathrm{nCoV}$ 19 infection admitted to Tongji Hospital from 26/1 - 5/02/2020 with follow up until

$$
03 / 03 / 2020
$$

150 adult patients with $\mathrm{nCoV}$ 19 infection admittedd to the fever wards Tongji Hospitals from January 2019 to February

$$
2020
$$

1012 non-critically ill adul

Wang 2020 Low Wuhan, Retrospective $\begin{gathered}\text { patients with nCoV-19 } \\ \text { infection admitted to Dongxihu }\end{gathered}$ cohort Fangcang Hospital between 07/02-12/02/2020

rogression to severe

COVID-19 defined as

at least one of the

followings, respiratory

rate $\geq 30$ breaths $/ \mathrm{min}$,

resting oxygen

saturation $\leq 93 \%$,
$\mathrm{PaO} 2 / \mathrm{FiO} 2 \leq 300$

$\mathrm{mmHg}$ or requirement

of mechanical

ventilation $\mathrm{OR}$

orsening of lung $\mathrm{CT}$

findings during the

observation period.

NHC - severe \&

critical

NHC - severe \& critical

Deterioration of COVID-19 defined as at least one of the following: (a) symptoms persisted or (b)respiratory rate $\geq 30$ or blood oxygen aturation $93 \%$, at rest (c) pulmonary it res; showed that the showed that the $>50 \%$ within 48 hours $>50 \%$ within 48 hours,
or (d) deterioration of co-morbidities or complications mentioned in items (f) 


\begin{tabular}{|c|c|c|c|c|c|c|c|c|c|c|c|c|}
\hline $\begin{array}{l}\text { Risk factors associated with } \\
\text { disease progression in a cohort } \\
\text { of patients infected with the } \\
2019 \text { novel coronavirus }^{82}\end{array}$ & Zhou & 2020 & $\begin{array}{l}\text { Low } \\
\text { quality }\end{array}$ & $\begin{array}{l}\text { Nanchang } \\
\text {, China }\end{array}$ & $\begin{array}{l}\text { Retrospective } \\
\text { cohort }\end{array}$ & $\begin{array}{c}17 \text { adult patients with nCoV-19 } \\
\text { infection admitted to the Ninth } \\
\text { Hospital of Nanchang between } \\
28 / 01-06 / 02 / 2020\end{array}$ & 35.3 & 41.5 & 5 & $\begin{array}{c}\text { Aggravation from } \\
\text { admission: increased } \\
\text { body temperature, } \\
\text { more serious } \\
\text { respiratory systems } \\
\text { and enlarging CT lung } \\
\text { lesions }\end{array}$ & 14 & 1 \\
\hline $\begin{array}{l}\text { Clinical Features and Short- } \\
\text { term Outcomes of } 102 \text { Patients } \\
\text { with Corona Virus Disease } \\
2019 \text { in Wuhan, China }{ }^{83}\end{array}$ & Cao & 2020 & $\begin{array}{l}\text { Low } \\
\text { quality }\end{array}$ & $\begin{array}{l}\text { Wuhan, } \\
\text { China }\end{array}$ & $\begin{array}{l}\text { Retrospective } \\
\text { cohort }\end{array}$ & $\begin{array}{l}102 \text { adult patients with nCoV- } \\
19 \text { infection admitted to } \\
\text { Wuhan University Zhongnan } \\
\text { between 03/01-01/02/2020 }\end{array}$ & 51 & 54 & 17 & Mortality & 16 & 6 \\
\hline $\begin{array}{c}\text { Clinical Characteristics of } 54 \\
\text { medical staff with COVID-19: } \\
\text { A retrospective study in a } \\
\text { single center in Wuhan, } \\
\text { China }^{84}\end{array}$ & Chu & 2020 & $\begin{array}{l}\text { Low } \\
\text { quality }\end{array}$ & $\begin{array}{l}\text { Wuhan, } \\
\text { China }\end{array}$ & $\begin{array}{l}\text { Retrospective } \\
\text { cohort }\end{array}$ & $\begin{array}{c}54 \text { adult medical staff with } \\
\text { nCoV-19 infection from Tongji } \\
\text { Hospital between } 0701- \\
11 / 02 / 2020\end{array}$ & 66.7 & 47 & 43 & $\begin{array}{c}\text { NHC - severe \& } \\
\text { critical }\end{array}$ & 7 & 2 \\
\hline $\begin{array}{l}\text { Clinical and Transmission } \\
\text { Characteristics of Covid-19 - A } \\
\text { Retrospective Study of } 25 \\
\text { Cases from a Single Thoracic } \\
\text { Surgery Department }{ }^{85}\end{array}$ & $\mathrm{Li}$ & 2020 & $\begin{array}{l}\text { Low } \\
\text { quality }\end{array}$ & $\begin{array}{l}\text { Wuhan, } \\
\text { China }\end{array}$ & $\begin{array}{l}\text { Retrospective } \\
\text { cohort }\end{array}$ & $\begin{array}{l}25 \text { adult patients with nCoV-19 } \\
\text { infection from Tongi Hospital's } \\
\text { Department of Thoracic } \\
\text { Surgery, including } 13 \text { admitted } \\
\text { patients and } 12 \text { healthcare staff, } \\
\text { from } 01 / 01-20 / 02 / 2020\end{array}$ & 76.9 & 60.2 & 9 & $\begin{array}{c}\text { NHC - severe \& } \\
\text { critical }\end{array}$ & 22 & 2 \\
\hline $\begin{array}{c}\text { Data Analysis of Coronavirus } \\
\text { CoVID-19 Epidemic in South } \\
\text { Korea Based on Recovered and } \\
\text { Death Cases }{ }^{86}\end{array}$ & $\begin{array}{c}\text { Al- } \\
\text { Rousan }\end{array}$ & 2020 & $\begin{array}{l}\text { Low } \\
\text { quality }\end{array}$ & $\begin{array}{l}\text { South } \\
\text { Korea }\end{array}$ & $\begin{array}{l}\text { Retrospective } \\
\text { cohort }\end{array}$ & $\begin{array}{c}2711 \text { patients with nCoV19 } \\
\text { infection with data entered into } \\
\text { the Korea Centers for Disease } \\
\text { Control and Prevention from } \\
20 / 01-29 / 03\end{array}$ & $\begin{array}{l}\text { Not } \\
\text { reported }\end{array}$ & $\begin{array}{l}\text { Not } \\
\text { reported }\end{array}$ & 9 & Mortality & 2 & 2 \\
\hline $\begin{array}{l}\text { Obesity in patients younger } \\
\text { than } 60 \text { years is a risk factor for } \\
\text { Covid-19 hospital admission }{ }^{87}\end{array}$ & Lighter & 2020 & $\begin{array}{l}\text { Low } \\
\text { quality }\end{array}$ & $\begin{array}{l}\text { New } \\
\text { York, } \\
\text { USA }\end{array}$ & $\begin{array}{l}\text { Retrospective } \\
\text { cohort }\end{array}$ & $\begin{array}{c}3615 \text { symptomatic adult } \\
\text { patients with nCoV-19 } \\
\text { infection who presented to } \\
\text { New York University hospital } \\
\text { system from } 04 / 03 \text { - } \\
04 / 04 / 2020\end{array}$ & $\begin{array}{l}\text { Not } \\
\text { reported }\end{array}$ & $\begin{array}{l}\text { Not } \\
\text { reported }\end{array}$ & 431 & $\begin{array}{l}\text { ICU admission or } \\
\text { invasive ventilator } \\
\text { documentation in } \\
\text { electronic health } \\
\text { record }\end{array}$ & 1 & 1 \\
\hline $\begin{array}{c}\text { Factors associated with } \\
\text { hospitalization and critical } \\
\text { illness among } 4,103 \text { patients } \\
\text { with COVID-19 disease in } \\
\text { New York City } \\
\end{array}$ & Petrilli & 2020 & $\begin{array}{l}\text { Low } \\
\text { quality }\end{array}$ & $\begin{array}{l}\text { New } \\
\text { York, } \\
\text { USA }\end{array}$ & $\begin{array}{l}\text { Cross- } \\
\text { sectional } \\
\text { analysis }\end{array}$ & $\begin{array}{l}4103 \text { patients with nCoV-19 } \\
\text { infection treated within New } \\
\text { York University Langone } \\
\text { Health inpatient and outpatient } \\
\text { systems between } 01 / 03-02 / 04 \\
\text { with follow up through } 07 / 04 \text {. }\end{array}$ & 50.5 & 52 & 650 & $\begin{array}{c}\text { ICU admission or } \\
\text { mechanical ventilation } \\
\text { or discharge to hospice } \\
\text { or death }\end{array}$ & 17 & 12 \\
\hline
\end{tabular}




\begin{tabular}{|c|c|c|c|c|c|c|c|c|c|c|c|c|}
\hline $\begin{array}{c}\text { Suspected myocardial injury in } \\
\text { patients with COVID-19: } \\
\text { Evidence from front-line } \\
\text { clinical observation in Wuhan, } \\
\text { China }^{89}\end{array}$ & Deng & 2020 & $\begin{array}{l}\text { Low } \\
\text { quality }\end{array}$ & $\begin{array}{l}\text { Wuhan, } \\
\text { China }\end{array}$ & $\begin{array}{l}\text { Retrospective } \\
\text { cohort }\end{array}$ & $\begin{array}{l}112 \text { adult patients with } \mathrm{nCoV}- \\
19 \text { infection admitted to } \\
\text { Renmin Hospital of Wuhan } \\
\text { University with symptom onset } \\
\text { from } 06 / 01-20 / 02 / 2020\end{array}$ & 50.9 & 65 & 67 & $\begin{array}{c}\text { NHC - severe \& } \\
\text { critical }\end{array}$ & 25 & 16 \\
\hline $\begin{array}{l}\text { Clinical characteristics and } \\
\text { outcomes of patients } \\
\text { undergoing surgeries during } \\
\text { the incubation period of } \\
\text { COVID-19 infection }\end{array}$ & Lei & 2020 & $\begin{array}{l}\text { Low } \\
\text { quality }\end{array}$ & $\begin{array}{l}\text { Wuhan, } \\
\text { China }\end{array}$ & $\begin{array}{l}\text { Retrospective } \\
\text { cohort }\end{array}$ & $\begin{array}{l}34 \text { adult patients who } \\
\text { underwent elective surgeries } \\
\text { and developed nCoV-19 } \\
\text { pneumonia post-operatively } \\
\text { with abnormal findings on } \\
\text { chest CT at Renmin Hospital, } \\
\text { Zhongnan Hospital, Tongji } \\
\text { Hospital and Central Hospital } \\
\text { from } 1 / 1-05 / 02 / 2020\end{array}$ & 41.2 & 55 & 15 & ICU admission & 21 & 4 \\
\hline $\begin{array}{l}\text { Risk factors of fatal outcome in } \\
\text { hospitalized subjects with } \\
\text { coronavirus disease } 2019 \text { from } \\
\text { a nationwide analysis in } \\
\text { China }^{91}\end{array}$ & Chen & 2020 & $\begin{array}{l}\text { Low } \\
\text { quality }\end{array}$ & China & $\begin{array}{l}\text { Retrospective } \\
\text { cohort }\end{array}$ & $\begin{array}{c}1590 \text { adult patients with nCoV- } \\
19 \text { infection admitted to } 575 \\
\text { hospitals throughout China } \\
\text { from December } 2019 \text { to } \\
31 / 1 / 2020\end{array}$ & $\begin{array}{l}\text { Not } \\
\text { reported }\end{array}$ & $\begin{array}{l}\text { Not } \\
\text { reported }\end{array}$ & 50 & Mortality & 7 & 5 \\
\hline $\begin{array}{l}\text { Prognostic value of myocardial } \\
\text { injury in patients with COVID- } \\
\qquad 19^{92}\end{array}$ & Wang & 2020 & $\begin{array}{l}\text { Low } \\
\text { quality }\end{array}$ & $\begin{array}{l}\text { Wuhan, } \\
\text { China }\end{array}$ & $\begin{array}{l}\text { Retrospective } \\
\text { cohort }\end{array}$ & $\begin{array}{c}202 \text { adult patients with nCoV- } \\
19 \text { infection admitted to } \\
\text { People's Hospital of Wuhan } \\
\text { University from } 31 / 1- \\
05 / 02 / 2020\end{array}$ & 43.6 & 63 & 33 & Mortality & 21 & 11 \\
\hline $\begin{array}{l}\text { Analysis of baseline liver } \\
\text { biochemical parameters in } 324 \\
\text { cases with novel coronavirus } \\
\text { pneumonia in Shanghai area }{ }^{93}\end{array}$ & Qian & 2020 & $\begin{array}{l}\text { Low } \\
\text { quality }\end{array}$ & $\begin{array}{l}\text { Shanghai, } \\
\text { China }\end{array}$ & $\begin{array}{l}\text { Retrospective } \\
\text { cohort }\end{array}$ & $\begin{array}{c}324 \text { adult patients with nCoV- } \\
19 \text { pneumonia admitted to } \\
\text { Shanghai Public Health } \\
\text { Clinical Center from 20/1- } \\
\text { 24/2/20 }\end{array}$ & 51.5 & 51 & 26 & $\begin{array}{c}\text { NHC - severe \& } \\
\text { critical }\end{array}$ & 12 & 7 \\
\hline $\begin{array}{l}\text { High prevalence of obesity in } \\
\text { severe acute respiratory } \\
\text { syndrome coronavirus-2 } \\
\text { (SARS-CoV-2) requiring } \\
\text { invasive mechanical } \\
\text { ventilation }^{94}\end{array}$ & Simonnet & 2020 & $\begin{array}{l}\text { Low } \\
\text { quality }\end{array}$ & $\begin{array}{l}\text { Lille, } \\
\text { France }\end{array}$ & $\begin{array}{l}\text { Retrospective } \\
\text { cohort }\end{array}$ & $\begin{array}{l}124 \text { consecutive adult patients } \\
\text { with nCoV-19 infection } \\
\text { admitted to Roger Salengro } \\
\text { Hospital at "Centre Hospitalier } \\
\text { Universitaire de Lille" between } \\
\text { 26/2-5/04/2020 }\end{array}$ & 73 & 60 & 85 & $\begin{array}{c}\text { Invasive mechanical } \\
\text { ventilation }\end{array}$ & 5 & 3 \\
\hline $\begin{array}{l}\text { C-reactive protein correlates } \\
\text { with CT findings and predicts } \\
\text { severe COVID-19 early }\end{array}$ & Tan & 2020 & $\begin{array}{l}\text { Low } \\
\text { quality }\end{array}$ & $\begin{array}{l}\text { Hunan, } \\
\text { China }\end{array}$ & $\begin{array}{l}\text { Retrospective } \\
\text { cohort }\end{array}$ & $\begin{array}{c}27 \text { consecutive adult inpatients } \\
\text { with nCoV-19 infection } \\
\text { admitted to Hunan Provincial } \\
\text { People's Hospital from 18/01- } \\
10 / 02 / 2020\end{array}$ & 41 & 48.9 & 6 & NHC - severe & 6 & 3 \\
\hline $\begin{array}{l}\text { Baseline Characteristics and } \\
\text { Outcomes of } 1591 \text { Patients } \\
\text { Infected With SARS-CoV-2 } \\
\text { Admitted to ICUs of the } \\
\text { Lombardy Region, Italy }\end{array}$ & Grasselli & 2020 & $\begin{array}{l}\text { Low } \\
\text { quality }\end{array}$ & $\begin{array}{l}\text { Lombardy } \\
\text {, Italy }\end{array}$ & $\begin{array}{l}\text { Retrospective } \\
\text { case series }\end{array}$ & $\begin{array}{l}1591 \text { critically ill patients with } \\
\text { nCoV-19 infection admitted } \\
\text { from } 20 / 2-18 / 03 / 2020\end{array}$ & 82 & 63 & 405 & Mortality & 2 & 2 \\
\hline
\end{tabular}




\begin{tabular}{|c|c|c|c|c|c|c|c|c|c|c|c|c|}
\hline $\begin{array}{l}\text { Clinical analysis on risk factors } \\
\text { for COVID-19 patients } \\
\text { becoming severe patients }^{96}\end{array}$ & Ling & 2020 & $\begin{array}{l}\text { Low } \\
\text { quality }\end{array}$ & $\begin{array}{l}\text { Shanghai, } \\
\text { China }\end{array}$ & $\begin{array}{l}\text { Retrospective } \\
\text { cohort }\end{array}$ & $\begin{array}{c}292 \text { adult patients with } \mathrm{nCoV}- \\
19 \text { infection admitted to } \\
\text { Shanghai Public Health } \\
\text { Clinical Center from 20/1- } \\
10 / 2 / 2020\end{array}$ & 52.7 & 49.9 & 21 & $\begin{array}{c}\text { NHC - severe \& } \\
\text { critical }\end{array}$ & 20 & 17 \\
\hline $\begin{array}{c}\text { Clinical Characteristics of } \\
\text { Older Patients Infected with } \\
\text { COVID-19: A Descriptive } \\
\text { Study }{ }^{97}\end{array}$ & Niu & 2020 & $\begin{array}{l}\text { Low } \\
\text { quality }\end{array}$ & $\begin{array}{l}\text { Beijing, } \\
\text { China }\end{array}$ & $\begin{array}{l}\text { Retrospective } \\
\text { cohort }\end{array}$ & $\begin{array}{c}141 \text { patients }>50 \text { yo with } \\
\text { nCOV-19 infection transferred } \\
\text { from general hospitals to } \\
\text { designated hospitals by Beijing } \\
\text { EMS from } 20 / 1-29 / 2 / 2020\end{array}$ & 56.7 & $\begin{array}{l}\text { Not } \\
\text { reported }\end{array}$ & 5 & Mortality & 1 & 1 \\
\hline
\end{tabular}

* Quality and bias were assessed using the Grading of Recommendations, Assessment, Development and Evaluations (GRADE) framework. ${ }^{27}$

** Study variables included were those of interest, defined as those related to patient demographics and history, and clinical presentation and investigation. 
medRxiv preprint doi: https://doi.org/10.1101/2020.04.23.20076653; this version posted April 27, 2020. The copyright holder for this preprint

(which was not certified by peer review) is the author/funder, who has granted medRxiv a license to display the preprint in perpetuity.

It is made available under a CC-BY-NC-ND 4.0 International license.

Table 2. Definitions of illness severity

\begin{tabular}{|c|c|}
\hline Illness severity definition & $\begin{array}{l}\text { Papers using definition } \\
(\mathrm{n}(\%))\end{array}$ \\
\hline $\mathrm{NHC}^{*}$ definition of severe \& critical ${ }^{* *}$ & $21(33.3)$ \\
\hline Inpatient mortality & $14(22.2)$ \\
\hline ICU admission & $6(9.5)$ \\
\hline NHC* definition of severe** & $3(4.8)$ \\
\hline "Severe", without additional description & $3(4.8)$ \\
\hline $\mathrm{NHC}^{*}$ definition of critical ${ }^{* *}$ & $2(3.2)$ \\
\hline Acute respiratory distress syndrome & $1(1.6)$ \\
\hline $\begin{array}{l}\text { Aggravation following admission: increased body temperature, more serious respiratory systems and } \\
\text { enlarging CT lung lesions }\end{array}$ & $1(1.6)$ \\
\hline $\begin{array}{l}\text { Deterioration of COVID- } 19 \text { defined as at least one of the following: (a) symptoms persisted or } \\
\text { worsened for }>7 \text { days; (b)respiratory rate } \geq 30 \text { or blood oxygen saturation } 93 \% \text {, at rest; (c) pulmonary } \\
\text { imaging showed that the lesions progressed }>50 \% \text { within } 48 \text { hours; or (d) deterioration of co- } \\
\text { morbidities or complications mentioned in items (f) to (i) of manuscript. }\end{array}$ & $1(1.6)$ \\
\hline Dyspnoea or respiratory failure & $1(1.6)$ \\
\hline Hospital stay $>10$ days & $1(1.6)$ \\
\hline ICU admission or invasive ventilator documentation in electronic health record & $1(1.6)$ \\
\hline ICU admission or mechanical ventilation or death & $1(1.6)$ \\
\hline ICU admission or mechanical ventilation or discharge to hospice or death & $1(1.6)$ \\
\hline Invasive mechanical ventilation & $1(1.6)$ \\
\hline Mechanical ventilation & $1(1.6)$ \\
\hline $\begin{array}{l}\text { Progression to severe COVID-19 by NHC severe or worsening of lung CT findings during the } \\
\text { observation period }\end{array}$ & $1(1.6)$ \\
\hline Progression to NHC definition of severe or critical condition, or death & $1(1.6)$ \\
\hline $\begin{array}{l}\text { Severe pneumonia characterised by fever, cough, dyspnoea, bilateral pulmonary infiltrates, and acute } \\
\text { respiratory injury }\end{array}$ & $1(1.6)$ \\
\hline $\mathrm{SpO}_{2}<90 \%$ & $1(1.6)$ \\
\hline
\end{tabular}

*NHC = National Health Committee of People's Republic of China.

**NHC stratifies illness into three categories: mild (slight clinical symptoms, with few or no respiratory symptoms and no pneumonia manifestations on imaging); severe (respiratory distress, $R R \geq 30$ breaths/min, resting $\mathrm{SpO} 2 \leq 93 \%$, and $\mathrm{PaO} 2 / \mathrm{FiO} 2 \leq 300 \mathrm{mmHg}$ ); and critical (respiratory failure, shock, and combined failure of other organs requiring mechanical ventilation and ICU-level care) ${ }^{98}$. 
medRxiv preprint doi: https://doi.org/10.1101/2020.04.23.20076653; this version posted April 27, 2020. The copyright holder for this preprint (which was not certified by peer review) is the author/funder, who has granted medRxiv a license to display the preprint in perpetuity.

It is made available under a CC-BY-NC-ND 4.0 International license.

Table 3. Demographic and historical variables significantly associated with illness severity*

\begin{tabular}{|c|c|c|}
\hline Variable & $\begin{array}{l}\text { Reported as significant* } \\
(\text { (n }(\%))\end{array}$ & Papers reporting variable (n) \\
\hline \multicolumn{3}{|l|}{ Demographics } \\
\hline Age & $47(87)$ & 54 \\
\hline Sex & $16(36)$ & 45 \\
\hline \multicolumn{3}{|l|}{ History of comorbidities } \\
\hline Hypertension & $22(67)$ & 33 \\
\hline Any pre-existing condition & $17(74)$ & 23 \\
\hline Cardiovascular disease & $16(64)$ & 25 \\
\hline Diabetes & $13(41)$ & 32 \\
\hline Body mass index (BMI) & $6(55)$ & 11 \\
\hline Chronic obstructive pulmonary disease (COPD) & $6(32)$ & 19 \\
\hline Stroke & $5(42)$ & 12 \\
\hline Malignancy & $5(26)$ & 19 \\
\hline Chronic kidney disease (CKD) & $4(29)$ & 14 \\
\hline Other respiratory disease & $2(29)$ & 7 \\
\hline Current smoker & $1(9)$ & 11 \\
\hline Tuberculosis & $0(0)$ & 3 \\
\hline Hepatitis/cirrhosis & $0(0)$ & 14 \\
\hline Immunocompromised & $0(0)$ & 2 \\
\hline
\end{tabular}

*Significance denoted by $\mathrm{p}<0.05$ as related to illness severity by definition specified in paper. 
medRxiv preprint doi: https://doi.org/10.1101/2020.04.23.20076653; this version posted April 27, 2020. The copyright holder for this preprint (which was not certified by peer review) is the author/funder, who has granted medRxiv a license to display the preprint in perpetuity.

It is made available under a CC-BY-NC-ND 4.0 International license .

Table 4. Clinical presentation variables significantly associated with illness severity*

\begin{tabular}{|c|c|c|}
\hline Variable & $\begin{array}{l}\text { Reported as significant* } \\
(\mathrm{n}(\%))\end{array}$ & $\begin{array}{c}\text { Papers reporting variable } \\
\text { (n) }\end{array}$ \\
\hline \multicolumn{3}{|l|}{ Presenting symptoms } \\
\hline Dyspnoea/difficulty in breathing/chest tightness & $16(67)$ & 24 \\
\hline Fever and/or chills & $6(23)$ & 26 \\
\hline Sputum production/expectoration & $3(23)$ & 13 \\
\hline Abdominal pain & $2(25)$ & 8 \\
\hline Pharyngalgia/sore throat & $1(13)$ & 8 \\
\hline Anorexia/nausea/vomiting & $1(8)$ & 13 \\
\hline Headache & $1(8)$ & 13 \\
\hline Fatigue & $1(5)$ & 21 \\
\hline Diarrhoea & $1(5)$ & 19 \\
\hline Cough & $1(4)$ & 25 \\
\hline Myalgias & $0(0)$ & 21 \\
\hline Haemoptysis & $0(0)$ & 5 \\
\hline Rhinorrhoea & $0(0)$ & 4 \\
\hline Confusion/altered mental status & $0(0)$ & 1 \\
\hline \multicolumn{3}{|l|}{ Initial vitals** } \\
\hline Respiratory rate & $6(60)$ & 10 \\
\hline $\mathrm{SpO} 2$ & $4(80)$ & 5 \\
\hline Fever & $4(33)$ & 12 \\
\hline Systolic blood pressure (SBP) & $2(40)$ & 5 \\
\hline Sequential Organ Failure Assessment (SOFA) & $1(100)$ & 1 \\
\hline Quick Sequential Organ Failure Assessment (qSOFA) & $1(100)$ & 1 \\
\hline Heart rate & $1(14)$ & 7 \\
\hline Diastolic blood pressure (DBP) & $1(33)$ & 3 \\
\hline
\end{tabular}

*Significance denoted by $\mathrm{p}<0.05$ as related to illness severity by definition specified in paper.

**No data were available on the predictive value of abnormal auscultation. 
medRxiv preprint doi: https://doi.org/10.1101/2020.04.23.20076653; this version posted April 27, 2020. The copyright holder for this preprint (which was not certified by peer review) is the author/funder, who has granted medRxiv a license to display the preprint in perpetuity.

It is made available under a CC-BY-NC-ND 4.0 International license.

Table 5. Clinical investigation variables significantly associated with illness severity*

\begin{tabular}{|c|c|c|}
\hline Variable & $\begin{array}{c}\text { Reported as significant* } \\
(\mathrm{n}(\%))\end{array}$ & Papers reporting variable (n) \\
\hline \multicolumn{3}{|l|}{ Laboratory findings } \\
\hline Lymphocyte (absolute count) & $24(77)$ & 31 \\
\hline Lactate dehydrogenase (LDH) & $21(81)$ & 26 \\
\hline C-reactive protein (CRP) & $20(80)$ & 25 \\
\hline D-dimer & $18(86)$ & 21 \\
\hline Procalcitonin & $16(76)$ & 21 \\
\hline Aspartate aminotransferase & $15(60)$ & 25 \\
\hline Neutrophils (absolute count) & $13(68)$ & 19 \\
\hline $\begin{array}{l}\text { Leucocytes/White Blood Count (WBC, absolute } \\
\text { count) }\end{array}$ & $13(48)$ & 27 \\
\hline Albumin & $12(75)$ & 16 \\
\hline Total bilirubin & $9(56)$ & 16 \\
\hline Creatinine & $9(45)$ & 20 \\
\hline Alanine aminotransferase (ALT) & $9(35)$ & 26 \\
\hline Interleukin-6 & $8(80)$ & 10 \\
\hline Platelets & $8(50)$ & 16 \\
\hline Creatinine kinase-MB & $7(78)$ & 9 \\
\hline Blood urea nitrogen (BUN) & $7(70)$ & 10 \\
\hline Prothrombin time (PT) & $6(50)$ & 12 \\
\hline Ferritin & $6(86)$ & 7 \\
\hline $\mathrm{CD} 8+\mathrm{T}$ cell markers & $6(75)$ & 8 \\
\hline $\mathrm{PaO}_{2} / \mathrm{FiO}_{2}$ & $5(100)$ & 5 \\
\hline N-terminal b-type natriuretic peptide (NT-proBNP) & $5(100)$ & 5 \\
\hline Blood Glucose & $4(100)$ & 4 \\
\hline Myoglobin & $4(80)$ & 5 \\
\hline Lymphocytes (\%) & $3(75)$ & 4 \\
\hline Neutrophils (\%) & $3(75)$ & 4 \\
\hline Interleukin-2, Interleukin 2 Receptor (IL-2, IL-2r) & $3(60)$ & 5 \\
\hline Interleukin-10 (IL-10) & $3(60)$ & 5 \\
\hline Erythrocyte Sedimentation Rate (ESR) & $3(27)$ & 11 \\
\hline B-type natriuretic peptide (BNP) & $2(67)$ & 3 \\
\hline Potassium & $2(67)$ & 3 \\
\hline Fibrinogen & $2(50)$ & 4 \\
\hline Tumour necrosis factor alpha (TNF $\alpha)$ & $2(33)$ & 6 \\
\hline Haemoglobin & $2(15)$ & 13 \\
\hline Basophils (\%) & $1(100)$ & 1 \\
\hline
\end{tabular}


medRxiv preprint doi: https://doi.org/10.1101/2020.04.23.20076653; this version posted April 27, 2020. The copyright holder for this preprint (which was not certified by peer review) is the author/funder, who has granted medRxiv a license to display the preprint in perpetuity. It is made available under a CC-BY-NC-ND 4.0 International license .

\begin{tabular}{|c|c|c|}
\hline Eosinophils (\%) & $1(100)$ & 1 \\
\hline Fibrin Degradation Product & $1(100)$ & 1 \\
\hline Granzyme B & $1(100)$ & 1 \\
\hline Leucocytes/White Blood Count (WBC, \%) & $1(100)$ & 1 \\
\hline Perforin & $1(100)$ & 1 \\
\hline Thrombin time & $1(100)$ & 1 \\
\hline Alkaline phosphatase (ALP) & $1(50)$ & 2 \\
\hline Complement 3 (C3) & $1(50)$ & 2 \\
\hline Cystatin C (CysC) & $1(50)$ & 2 \\
\hline Eosinophils (absolute count) & $1(50)$ & 2 \\
\hline Interferon- $\gamma(\mathrm{INF}-\gamma)$ & $1(50)$ & 2 \\
\hline International normalised ratio (INR) & $1(50)$ & 2 \\
\hline Monocyte (\%) & $1(50)$ & 2 \\
\hline Interleukin-8 (IL-8) & $1(33)$ & 3 \\
\hline Immunoglobulin G (IgG) & $1(33)$ & 3 \\
\hline Immunoglobulin M (IgM) & $1(33)$ & 3 \\
\hline Total protein & $1(33)$ & 3 \\
\hline Sodium & $1(25)$ & 4 \\
\hline Partial thromboplastin time (PTT) & $1(11)$ & 9 \\
\hline Monocyte (absolute count) & $0(0)$ & 10 \\
\hline Gamma-glutamyl transferase (GGT) & $0(0)$ & 3 \\
\hline Interleukin-1 beta (IL-1 $\beta$ ) & $0(0)$ & 3 \\
\hline Immunoglobulin A (IgA) & $0(0)$ & 3 \\
\hline Anti-Thrombin Activity & $0(0)$ & 1 \\
\hline Complement 4 (C4) & $0(0)$ & 2 \\
\hline Basophils (absolute count) & $0(0)$ & 1 \\
\hline Haematocrit & $0(0)$ & 1 \\
\hline Serum chloride & $0(0)$ & 1 \\
\hline Serum urea nitrogen & $0(0)$ & 1 \\
\hline \multicolumn{3}{|l|}{ Imaging findings** } \\
\hline Abnormal CT & $10(63)$ & 16 \\
\hline Abnormal chest X-ray & $2(50)$ & 4 \\
\hline Normal CT & $1(50)$ & 2 \\
\hline
\end{tabular}

*Significance denoted by $\mathrm{p}<0.05$ as related to illness severity by definition specified in paper.

**No data were available on the predictive value of normal chest X-rays. 
medRxiv preprint doi: https://doi.org/10.1101/2020.04.23.20076653; this version posted April 27, 2020. The copyright holder for this preprint (which was not certified by peer review) is the author/funder, who has granted medRxiv a license to display the preprint in perpetuity. It is made available under a CC-BY-NC-ND 4.0 International license.

\section{Appendix: Search strategy}

\section{PubMed}

Search date: $19 / 4 / 20$

Restricted to studies published from 1/12/19-19/4/20

\# $\quad$ Search terms

No. results

NCoV [TIAB] OR Coronavirus [MesH] OR “severe acute respiratory syndrome coronavirus 2” [MesH]

1 OR "COVID*" [TIAB] OR "COVID-19" [TIAB] OR Coronavirus infections [MesH] or "coronavirus"

[TIAB]

Severity of Illness Index [MesH] OR "sever*" [TIAB] OR "critical*" [TIAB] OR Patient Admission

[MesH] OR Length of Stay [MeSH] OR Critical Illness [MeSH] OR Critical care [MeSH] OR Outcome*

2 [TIAB] OR Mortality [MeSH] OR Death [MeSH] OR Morbidity [MeSH] OR Respiratory Insufficiency

106821

[MeSH] OR Respiratory Distress Syndrome, Adult [MESH] OR Respiration, Artificial [MeSH] OR

"ventilation" [TIAB]

3 Demography [MesH] OR “Age” [TIAB] OR “Sex" [TIAB] OR “Gender” [TIAB]

4 Comorbidity [MesH] OR "Co-morbid*" [TIAB] OR "Comorbid*” [TIAB] OR "Pre-exist*" [TIAB] OR "Condition*" [TIAB]

5 Signs and Symptoms [MeSH] OR "symptom*” [TIAB] OR "characteristic*” OR "clinical” OR "presentation*" [TIAB]

Diagnostic Techniques and Procedures [MeSH] OR "Imag*" OR "X-ray*" OR "Xray*" OR "CT" OR "Computed Tomography" OR "Radiograph*" 
medRxiv preprint doi: https://doi.org/10.1101/2020.04.23.20076653; this version posted April 27, 2020. The copyright holder for this preprint (which was not certified by peer review) is the author/funder, who has granted medRxiv a license to display the preprint in perpetuity. It is made available under a CC-BY-NC-ND 4.0 International license.

\section{Scopus}

Search date: $19 / 4 / 20$

Restricted to studies published from 1/1/19-19/4/20

\begin{tabular}{|c|c|c|}
\hline \# & Search terms & No. results \\
\hline 1 & $\begin{array}{l}\text { TITLE-ABS-KEY(NCoV OR severe acute respiratory syndrome coronavirus } 2 \text { OR COVID* OR COVID- } \\
19 \text { OR coronavirus) }\end{array}$ & 828 \\
\hline 2 & $\begin{array}{l}\text { TITLE-ABS-KEY("severity of illness index" OR sever* OR critical* OR "patient admission" OR "length of } \\
\text { stay" OR "critical illness" OR "critical care" OR outcome* OR mortality OR death OR morbidity OR } \\
\text { respiratory AND insufficiency OR "respiratory distress syndrome" OR respiration OR ventilation) }\end{array}$ & 24468 \\
\hline 3 & TITLE-ABS-KEY(demograph* OR age OR sex OR gender) & 132302 \\
\hline 4 & TITLE-ABS-KEY(comorbidity OR co-morbid* OR comorbid* OR pre-exist* OR preexist OR condition*) & 556058 \\
\hline 5 & TITLE-ABS-KEY("signs and symptoms" OR symptom* OR characteristic* OR clinical OR presentation*) & 1001095 \\
\hline 6 & $\begin{array}{l}\text { TITLE-ABS-KEY(diagnostic OR techniques OR procedures OR invest*OR imag* OR X-ray* OR Xray* } \\
\text { OR CT OR Computed Tomography OR radiograph*) }\end{array}$ & 46425 \\
\hline 7 & $1+2+3$ & 28 \\
\hline 8 & $1+2+4$ & 32 \\
\hline 9 & $1+2+5$ & 60 \\
\hline 10 & $1+2+6$ & 7 \\
\hline
\end{tabular}


medRxiv preprint doi: https://doi.org/10.1101/2020.04.23.20076653; this version posted April 27, 2020. The copyright holder for this preprint (which was not certified by peer review) is the author/funder, who has granted medRxiv a license to display the preprint in perpetuity. It is made available under a CC-BY-NC-ND 4.0 International license.

\section{Web of Science}

Search date: $19 / 4 / 20$

Restricted to studies published from 1/1/19-31/3/20

\begin{tabular}{|c|c|c|}
\hline$\#$ & Search terms & No. results \\
\hline 1 & $\mathrm{TS}=(\mathrm{COVID} *$ OR NCoV OR Coronavirus* OR SARS-CoV-2) & 1132 \\
\hline 2 & $\begin{array}{l}\mathrm{TS}=(\text { Sever* OR Critical* OR Admit* OR Admission* OR Length of stay* OR Critical Care OR Intensive } \\
\text { Care OR Outcome OR Mortality OR Death OR Morbidity OR Respiratory Failure OR Respiratory } \\
\text { Distress OR Respiration OR Ventilation) }\end{array}$ & 625363 \\
\hline 3 & $\mathrm{TS}=($ Demograph* OR Age* OR Gender* OR Sex*) & 397718 \\
\hline 4 & $\mathrm{TS}=($ Comorbid* OR Co-morbid* OR Preexist* OR Pre-exist* OR Condition*) & 358857 \\
\hline 5 & TS $=($ Symptom* OR Sign* OR Characteristic* OR Clinical* OR Present*) & 1363307 \\
\hline 6 & TS=(Vital* OR Vital* Sign*) & 24207 \\
\hline 7 & TS $=($ Blood* OR Blood Test* OR Laboratory* OR Investigat* OR Blood Count*) & 653308 \\
\hline 8 & TS=(Imaging OR Image OR X-ray* or Xray* OR CT OR Computed Tomography OR Radiograph*) & 260291 \\
\hline 9 & $1+2+3$ & 165 \\
\hline 10 & $1+2+4$ & 59 \\
\hline 11 & $1+2+5$ & 442 \\
\hline 12 & $1+2+6$ & 12 \\
\hline 13 & $1+2+7$ & 203 \\
\hline 14 & $1+2+8$ & 57 \\
\hline
\end{tabular}

